\title{
Progressive glaciotectonic deformation in Weichselian and Palaeogene deposits at Feggeklit, northern Denmark
}

\author{
STIG ASBJØRN SCHACK PEDERSEN
}

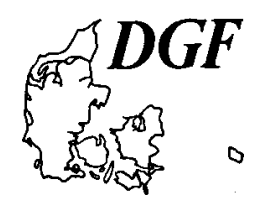

Pedersen, S.A.S.: Progressive glaciotectonic deformation in Weichselian and Palaeogene deposits at Feggeklit, northern Denmark. Bulletin of the Geological Society of Denmark, Vol. 42, pp. 153-174, Copenhagen 1996-02-01. https://doi.org/10.37570/bgsd-1995-42-13

\begin{abstract}
Structural analysis of the glaciotectonic deformations at Feggeklit, Mors, Denmark, provide a unique record of succesive deformation phases in a progressive glaciotectonic deformation. The Feggeklit profile displays glaciotectonically folded, thrust-faulted and sheared Palaeogene diatomite with thin volcanic ash layers, the Fur Formation, overlain by a glacigene succession. The combination of stratigraphical and structural analysis shows that the Feggeklit was affected by three glaciodynamic events. The first event is of Saalian age and is repre-sented by the deposition of a till and the formation of a para-authochthonous glacitectonite in the top of the Fur Formation deposits.

The second event is only represented by the deposition of a till, probably of Saalian age. The third event is of Late Weichselian age. It includes: 1) deposition of proglacial glaciolacustrine and -fluvial sediments, 2) the formation of a glaciotectonic unit (the Feggeklit deformation complex) and 3) deposition of a till resting on a tectonic uncon-formity formed subglacially.

A detailed structural analysis of the glaciotectonic unit provides a subdivision into five succesive deformation phases. The first four phases are related to the proglacial deformation and comprise 1) anastamosing jointing, 2) conjugate faulting, 3) buckle folding and listric thrust faulting, and 4) large scale ramp thrusting. The final phase (5) is related to subglacial shear deformation and loading which produced an allochthonous diatomiteglacitectonite at the sole of the overlying lodgement till.

The formation of the structural complex at Feggeklit was caused by two glaciotectonic mechanisms: 1) a proglacial gravity spreading deformation, and 2) a subglacial cataclastic shearing. The balanced cross-section of the fold structures related to the first deformation mechanism indicates that the detachment of the dislocation is situated below the base of the diatomite formation in the plastic clay at a depth of $80-100 \mathrm{~m}$ below the surface. Based on the glaciodynamic analysis and considerations on the dating of regional glacigenic setting the velocity of the advancing ice is estimated at $10 \mathrm{~m}$ per year. This advance created the gravity spreading deformation reflected in the glaciotectonic structures preserved in the Feggeklit.
\end{abstract}

S.A. Schack Pedersen. Geological Survey of Denmark and Greenland, Thoravej 8, DK 2400 Copenhagen, Denmark. 9th June 1995.

\section{Introduction}

Although Gry (1940) described the structures of the Palaeogene diatomite and ash layer deposits of the cliff sections along the coasts of the westem Lim-fjorden region as due to glacial tectonics the origin of these spetacular structures are still being questioned by visitors. The possibility of endogene tectonic deformations is of central importance since extensional deformation caused by subsidence, probably due to halokinetic movements, has been recorded from the Hanklit cliff section on Mors (Klint \& Pedersen 1995), and normal faulting of neotectonic origin has been recognized on Fur (Pedersen 1992, Pedersen \& Jakobsen 1993). However, these structures were all demonstrated to be su- perposed by or superimposing glaciotectonic stuctures.

Therefore this paper aims to demonstrate the glaciotectonic relationship through a structural analysis which provides the basis for the interpretation of the glaciotectonic development. The analysis comprises two steps: 1) an investigation of the relationship between individuel sets of structures, which enables a separation of sequential phases of deformations; and 2) the investigation of the cross section, including a balance of the section aiming at a retrodeformation of the structural complex.

The construction of balanced cross-sections (Dahlström 1969) has in the last couple of years achieved strong attention mainly due to the demand for correctly 


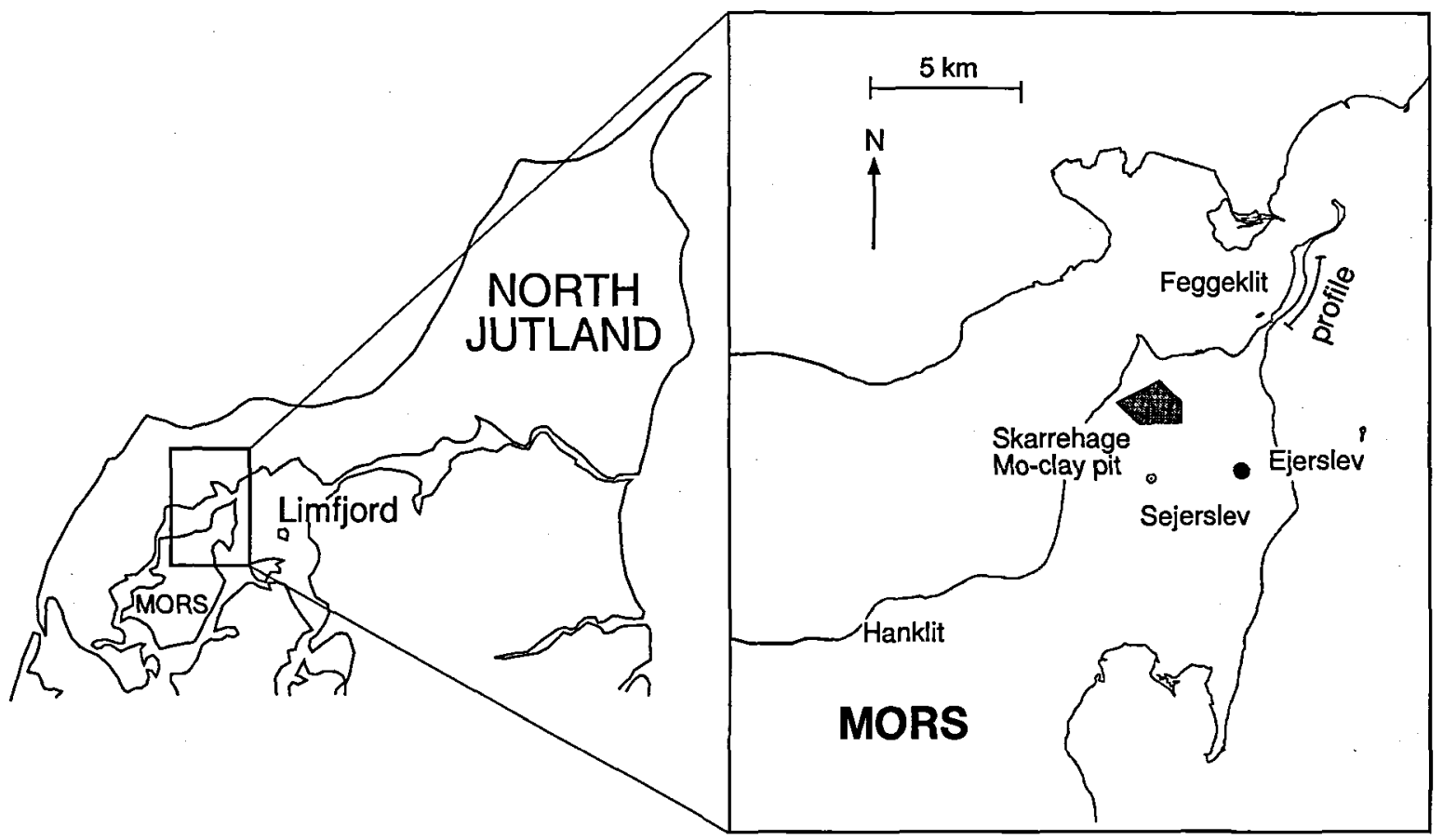

Fig. 2. Location map of Feggeklit situated in the northernmost peninsula on the island of Mors in the western part of the Limfjord, northern Denmark. Besides the location of the Skarrehage mo-clay pit is indicated.

interpreted structural profiles within the petroleum geology. Accordingly new sophistications has been added to the method and a specialized terminology has been introduced (e.g. Suppe 1985). In glaciotectonic investigations balanced cross sections has been applied by Croot (1989) for recent glaciotectonics in Iceland and by Klint \& Pedersen (1995) for Weichselian thrust faulting in Denmark. In this paper the technique of a balanced cross section is applied to solve the problem of retrodeformation in glaciotectonics, and it is demonstrated how the depth of the detachment surface may be calculated from the structures exposed in the Feggeklit profile (Fig. 1; inserted as foldout figure inside the back cover).

The investigated Feggeklit profile is a nearly one kilometer long coastal cliff section situated in the northern tip of the island of Mors (Fig. 2). The locality is known for its glaciotectonic decollement folds. The profile was first published by Gry (1940) in the paper concerning the glacial tectonic deformations of the Palaeogene mo-clay (the diatomite) in the western Limfjorden region, northern Jutland, Denmark (Fig. 2). The locality was first mentioned by Ussing (1904), the stratigraphy of Palaeogene volcanic ash layers was measured by Bøggild (1918), and the first structural study was made by Gry (1940). Gry's investigations were facilitated by the appearence of good exposures of the coastal cliffs. Intensive erosion in the thirties was due to an algal disease whereby wave-erosion was no longer dampened. Still the profile is not completely exposed, and since the last profile was published by Gry in 1979, even new parts of the profile have been exposed which add new information and corrections to Gry's profile (Fig 1).

The profile at Feggeklit is excellent for structural analysis because it is perpendicular to the main trend of glaciotectonic structures. Furthermore the detailed ash layer stratigraphy makes it possible to obtain a precise correlation of the deformed beds, and the detailed geometry of the stuctures are clearly outlined by the contrast between dark ash layers and pale diatomite (Fig. 1).

The main target of this structural investigation is to unravel the tectonic evolution of the structures and to demonstrate a progressive proglacial to sub-glacial deformation history of a Pleistocene glacio-tectonic deformation complex.

\section{Terminology}

Glaciotectonics is today recognized as a separate field in geology (Croot 1988, Aber et al. 1989, Wateren 1992). It has formerly been confused with glaciology, and glaciotectonic features has been misinterpreted as being of orogenic origin, but it has now been settled with 
its own identity. Glaciotectonics is one of the most conspicuous branches of soft sediment deformation, and it forms an integrated part of glaciodynamic analysis (Pedersen 1987, 1993).

The concept of glaciodynamic analysis introduces a number of new terms which are defined below. The glaciodynamic analysis attempts to deal with the duality between deposition and deformation. Berthelsen $(1973,1978)$ founded this approach by the introduction of the kineto-stratigraphical concept.

The kineto-stratigraphical analysis includes directional elements such as palaeocurrent, glacier movements deduced from till fabric, striations etc., and first of all deformation structures, in the stratigra-phical subdivision (Sørensen \& Nielsen 1978). A kinetostratigrapical scheme including the relevant directional elements was proposed by Houmark-Nielsen (1988). However, the aspects concerning deformation of bedrock could be expanded to exctract better informations from the glaciotectonic complexes.

In order to provide a better frame for the understanding of these aspects of glacial geology a glacio-tectonic event stratigraphy is suggested that includes glaciodynamically deposited sediments and glaciotectonically deformed rock units, either of glacigenic or non-glacigenic origin. The glaciodynamic sequence termi-nology includes the following terms (Pedersen 1993):

Glaciodynamic event: One regional glacial advance characterized by an unidirectional dynamic impact.

Glaciodynamic sequence: The result of a glaciodynamic event. The glaciodynamic sequence includes the sediments deposited in a glaciodynamic event, and the deposits affected by the glaciotectonic deformation during the event. The glaciodynamic sequence ideally includes a number of deposits not all of which need to be present. A basal erosional unconformity may separate proglacial meltwater deposits from older stratigraphical units. The proglacial deposits are dominantly fluvial but lacustrine deposits are commonly intercalated.

The glaciodynamic sequence includes a glaciotectonic unconformity. Beneath this the sediments are folded and thrusted, above it or coinciding with it glaciotectonic brecciation prevailed. The sediments beneath the tectonic unconformity may be amalgamated with those above.

The glaciotectonic unconformity is overlain by a lodgement till succeeded by meltwater deposits. Oscillating ice sheets deposit a number of tills interbedded within the meltwater deposits. The glacio-dynamic sequence is capped by an erosional uncon-formity generated by subaerial erosion.

Glaciotectonic unit: Sediments and sedimentary rocks deformed during the glacial advance constitutes the glaciotectonic unit (Pedersen 1993). In appropriate set- tings bedrock is included. The glacio-tectonic unit is part of a glaciodynamic sequence.

Kineto-stratigraphical unit: A till or composite till unit including a glacitectonite and the glaciofluvial sediments related to the advancing and the retreating ice margin respectively (modified from Berthel-sen 1978). The kineto-stratigraphical unit is part of a glaciodynamic sequence.

Glaciotectonic deformation: Deformation caused by a prograding glacier. The glaciotectonic deformation comprises at least two phases: 1) the proglacial foreland folding and thrusting, and 2) the subglacial shearing and cataclastic brecciation. Subglacial deformation leads to the formation of a distinct new lithology termed a glacitectonite (Pedersen 1988). Berthelsen (1978) suggested the terms domainal and extradomainal deformations which are partly identical with the model above. However, Berthelsen's concept of domainal deformations was exclusively related to deformation of the sediments within the kineto-stratigraphical unit, whereas extra-domainal denoted deformation of subjacent strata.

Glaciotectonic phases: Succesive deformation pha-ses within a glaciodynamic event. The glacio-tectonic phases are characterized by specific structures and their relationship marks the phases' succession. The glacial advance produces a diagnostic suite of deformation structures which may be distinguished in succesive deformation phases.

\section{Geological setting}

The Feggeklit is situated in the western part of the Limfjord region, northern Jutland (Fig. 2). The preQuaternary geology comprises Maastrichtian (Cretaceous) and Danian (Tertiary) limestones mainly cropping out in the northern part of the region. The limestones are overlain by Palaeocene and Eocene clays. In this part of Denmark these clay units constitute a series of more than $20 \mathrm{~m}$ thick fine-grained green and dark grey clay, the Holmehus and Ølst Formations, overlain by the Fur Formation. The Fur Formation comprises $60 \mathrm{~m}$ of clayey diatomite interbedded with 179 layers of volcanic ash which form the basis of a local stratigraphy (Bøggild 1918, Pe-dersen \& Surlyk 1983).

The Fur Formation extends over a large part of the western Limfjord region, where it occurs in allochtonous glaciotectonic thrust sheets (Gry 1940, 1979). Consequently the upper and lower boundaries of the formation are rarely exposed. Geological mapping indicates, however, that the Fur Formation overlies finegrained Paleocene green plastic clay, the Ølst Formation (Heilmann-Clausen et al. 1985). Except for some 
scarce reminents of Oligocene beds (Gry 1940, Pedersen 1989), the Fur Formation is unconformably overlain by Quaternary drift.

The Quaternary stratigraphy at Feggeklit includes three tills intercalated by various beds of glaciolacustrine and glaciofluviatile sediments. The lower and middle tills (Fig. 1, till units 1 and 2) are interpreted to be of Saalian age (S. Sjørring 1988, pers. comm.), based on stone countings and regional geological considerations). The uppermost till discordantly overlies the deformed beds including the underlying glaciolacustrine sediments. The uppermost till represents the Late Weichselian glacial advance that reached the Main Stationary Line in the central part of Jutland at about 18.000 years BP (Pedersen et al. 1988; Petersen \& Kronborg 1991).

The glaciotectonic deformations that affected the western Limfjord region were mainly produced by an ice movement directed from the north to the south (Gry 1940). Variations in deformation directions have been recorded and interpreted as shift in ice pressure dirctions due to a lobate ice deformation fronts (Gry 1940, 1979). Fold axes of the decollement folds in the Feggeklit profile are consistent with a general ice movement directed from the north to the south. However, variations in the axis directions may be ascribed to progressive thrusting along curved thrust planes or minor modifications during readvance of the retreating ice cap.

\section{Stratigraphy}

The stratigraphical units affected by the deformations comprising the structural complex at Feggeklit are the Palaeogene plastic clay (the Holmehus(?) and Ølst Formations) and the diatomite with ash layers of the Fur Formation. Above the Tertiary deposits a series of Quaternary glacigene sediments occur. The Quaternary stratigraphy is included in the local Feggeklit glacigene group, which may be separated into three galcio-dynamic sequences representing three glaciodynamic events (Pedersen 1993) (Fig. 3).

\section{The Holmehus and Ø1st Formations}

The Holmehus and Ølst Formations was erected by Heilmann-Clausen et al. (1985). The sediments comprise dark grey and greenish clay with a late Paleocene dinoflagellate assemblage. In the Ølst Formation a number of ash layers appear. The boundary between the $\varnothing 1$ st Formation and the Fur Formation is a diachronuos boundary. In the central part of Jutland the Fur Formation is absent whereas in the Limfjord region the upper part of the Ølst Formation is occupied by the Fur Formation (Heilmann-Clausen et al. 1985).

Informations of the $\emptyset$ lst Formation in the Feggeklit area is given from an exploration drilling in the
Skarrehage mo-clay pit c. $4 \mathrm{~km} \mathrm{SW}$ of Feggeklit (Pedersen \& Petersen, 1986). The drill hole is $42 \mathrm{~m}$ deep and penetrates the boundary between the Ølst Formation and the Fur Formation. The dark green plastic clay of the $\emptyset$ lst Formation is about $12 \mathrm{~m}$ thick. The true thickness is probably $10 \mathrm{~m}$ when reduced for the tilted bedding $(\cos \alpha$, where $\alpha$ is angle of dip which estimated from the outcrop in the pit is between $20^{\circ}$ and $30^{\circ}$ ). The lithology is a welsorted, silty clay, and the clay minerals are dominantly smectite and kaolinite. Based on the examination of the dinoflaggelates the unit was correlated to the Ølst Formation, whereas no diatoms were recognized (pers. comm. C. HeilmannClausen 1986).

Although the $\emptyset$ lst Formation was not penetrated it is evident that the very fine-grained clayish Holmehus Formation (Heilmann-Clausen et al. 1985) consisting exclusively of smectite is situated just below the bottom of the drill-hole. This is confirmed by the physical data from the drill-operation which stated that it is was actually impossible to pull out of the hole due to the dense character of the clay at the bottom, which resulted in the call-off of the drill operation.

A clay mineralogical investigation was carried out on the drill-core. This showed a marked change from a smectite rich clay composition above the distinct c. 10 $\mathrm{cm}$ thick ash layer -33 and a clay dominated by kaolinite below this ash layer (Pedersen \& Petersen 1986). Therefore the boundary between The Ølst and the Fur Formations is regarded to be situated at the base of ash layer -33 in the Skarrehage - Feggeklit area.

\section{The Fur Formation}

The Fur Formation is a c. $60 \mathrm{~m}$ thick Paleocene-Eocene diatomite with 179 interbedded ash layers. The formation was erected by Pedersen and Surlyk (1983), who divided the formation into the lower Knudeklint Member and the upper Silstrup Member. Bøggild (1918) numbered the volcanic ash layers in the lower member from -1 to -39 , and the upper member was given numbers from +1 to +140 .

\section{The Knudeklint Member}

The Knudeklint Member is c. $33 \mathrm{~m}$ thick and is only scarsly represented in the Feggeklit profile. The up-per boundary and the three easily recognized ash layers $11,-12$ and -13 are exposed in the hanging wall of the thrust in the central part of the profile. Thus the Knudeklint Member is inferred to be situated just below sea level throughout the Feggeklit peninsula. The member is well exposed in the Skarrehage mo-clay pit mentioned above. Here the lover-most c. $24 \mathrm{~m}$ of the formation consists of diatomite containing clayey silt clayrich diatomite. In the upper part of the clayey unit two chertified clay beds form red-brown marker hori- 

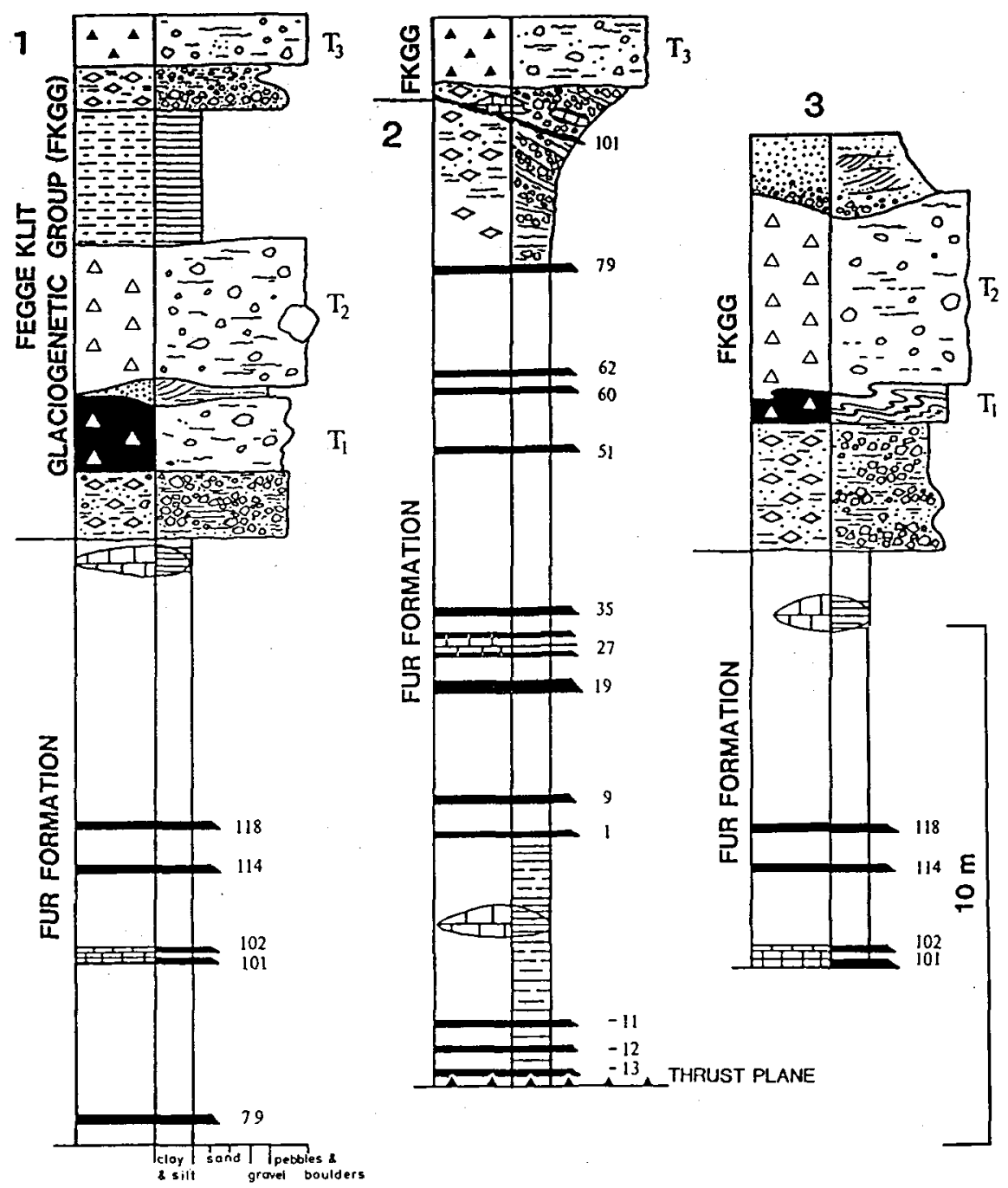

LITHOLOGY

volcanic ash layer in diatomite

STRUCTURES

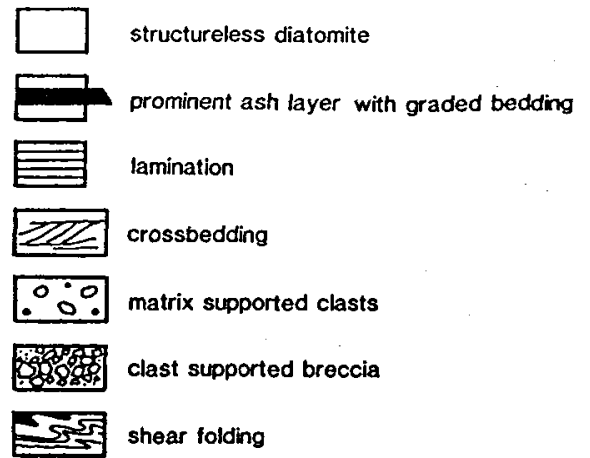

Fig. 3. Three lithological logs which show the stratigraphy displayed in the Feggeklit profile. No. 1 represents zone 1, no: 2 represents zone 2 , and no. 3 represents zone 3 , respectively. 
zons that outline many of the structural features, including folds and arrow head patterns, seen in the lowermost part of the mo-clay pit (Gry 1940; Pedersen 1983,1990 ). The diatomite above the chertified beds is light yellowish to oliven grey-brown and only few thin ash layers occur.

\section{Silstrup Member}

The Silstrup Member consist of a c. $27 \mathrm{~m}$ thick sequence of diatomite interlayered with 140 ash layers. This unit constitutes the main part of the lithology outcropping at Feggeklit. The exposed diatomite is in the dry part of the season white or light yellow-brown due to the appeareance of Feoxides; in the season with wet and cold weather the cliff appears oliven-greybrown. At the bottom of the member calcareous concretions occur as oblates about $2 \times 1,5 \times 0,5 \mathrm{~m}$ in size. Generally the ash layers are dark grey or black. The thickness varies from 1 to $10 \mathrm{~cm}$, but some of the easier recognizable ash layers are up to $15 \mathrm{~cm}$ thick. The ash layers consists of fine grained glass sand with a tholeiitic basaltic composition (Pedersen et al. 1975). However one exception is the $20 \mathrm{~cm}$ thick ash layer +19 which is a characteristic grey fine-grained to silty bed with an andesitic composition (Pedersen et al. 1975). In the upper part of the member ash layer +101 is included in the $35 \mathrm{~cm}$ thick red-brown calcareous concretionary bed, which forms an important marker bed in the structural investigation. The ash layers +114 and +118 form an easy recognizable marker horizon due to the considerable thickness of the ash layers. Inspected at close distance these two ash layers are identified by the presence of dish and pillar structues formed due to water escape from the fine sandy ash beds (Pedersen \& Surlyk 1977).

The uppermost $5 \mathrm{~m}$ of the Silstrup Member consists of diatomite with only a very few thin ash layers. At a distinct level in the middle of this unit calcareous concretions with a size about $2 \times 1,2 \times 0,5 \mathrm{~m}$ appear (the upper calcareous concretions annotated Ø.C. in Fig. 1).

\section{The Feggeklit glacigene group}

The sediments in the Feggeklit glacigene group are separated into three glaciodynamic sequences (Pedersen 1993). The primary units in this framework is the three tills, annotated T1, T2 and T3 (Fig. 3). A glacio-lacustrine unit interfingering with glaciofluvial deposits is included in the uppermost glacio-dynamic sequence.

\section{The first glaciodynamic sequence}

The deposit in this sequence is only represented by till unit T1.
Till unit T1. The lowermost glacigenic deposit in the Feggeklit profile is till unit $\mathrm{T} 1$. The till is resting on an erosional unconformity above a para-authoch-thoneous diatomite-glacitectonite in the top of the Fur Formation. In the southern part of the cross section the till is $100-120 \mathrm{~cm}$ thick, but in the northern part it has been sheared out to only $20 \mathrm{~cm}$. In the central part of the profile it has been eroded away. It is a dark grey clayey and slightly calcareous till with a minor content of erratic boulders. Till unit T1 is interpreted as belonging to the Saalian glaciation (S. Sjørring pers. comm. 1988), and it is overlain by an erosional unconformity. The unit between the two unconformities represent the first glaciodynamic se-quence.

\section{The second glaciodynamic sequence}

The deposits in this sequence constitutes till T2 and minor intercalations of meltwater sand and gravel.

Till unit T2. This is the most prominent unit in the glacigene group. It is a redbrown somewhat sandy till 2-5 m thick with a fairly high content of stones and boulders. Till T2 has been folded and thrust faulted during the main deformation of the Feggeklit profile, and it is probably of Saalian age (S. Sjørring 1988, pers. comm.). Along the contact between $\mathrm{T} 1$ and $\mathrm{T} 2$ small lenses of meltwater sand occur occasionally, but in general the contact is very sharp between the clayey and sandy tills.

$\mathrm{T} 2$ is overlain by an erosional unconformity upon which a glaciolacustrine unit is deposited. Floes of the T2 till have been thrusted up into imbricates, which Gry (1979) interpreted as an additional till. However, landsliding between $210 \mathrm{~m}$ and $250 \mathrm{~m}$ in the profile (Fig.1) in the early spring 1984 exposed the deformational details here presented. The glaciolacustrine beds are folded in an anticlinal "nose" around the major floe which shows that Gry's additional till is a repeated till T2. In the northern part of the central glaciolacustrine basin (Fig. 39 in Gry (1979)) the footwall syncline related to a minor thrust fault south of the ramp thrust in zone 2 (see later) is deformed into a recumbent syncline with $\mathrm{T} 2$ on the inverted limb. The second glaciodynamic sequence is represented by the till unit T2 and the "pockets" of meltwater sand between the erosional unconformity to $\mathrm{T} 1$ and the unconformity above $\mathrm{T} 2$.

\section{The third glaciodynamic sequence}

The deposits in this sequence are represented by glaciolacustrine, partly glaciofluvial, sediments and the till T3.

The glaciolacustrine unit. This unit occur above the unconformity on top of T2. It consists of a $2.5 \mathrm{~m}$ thick 

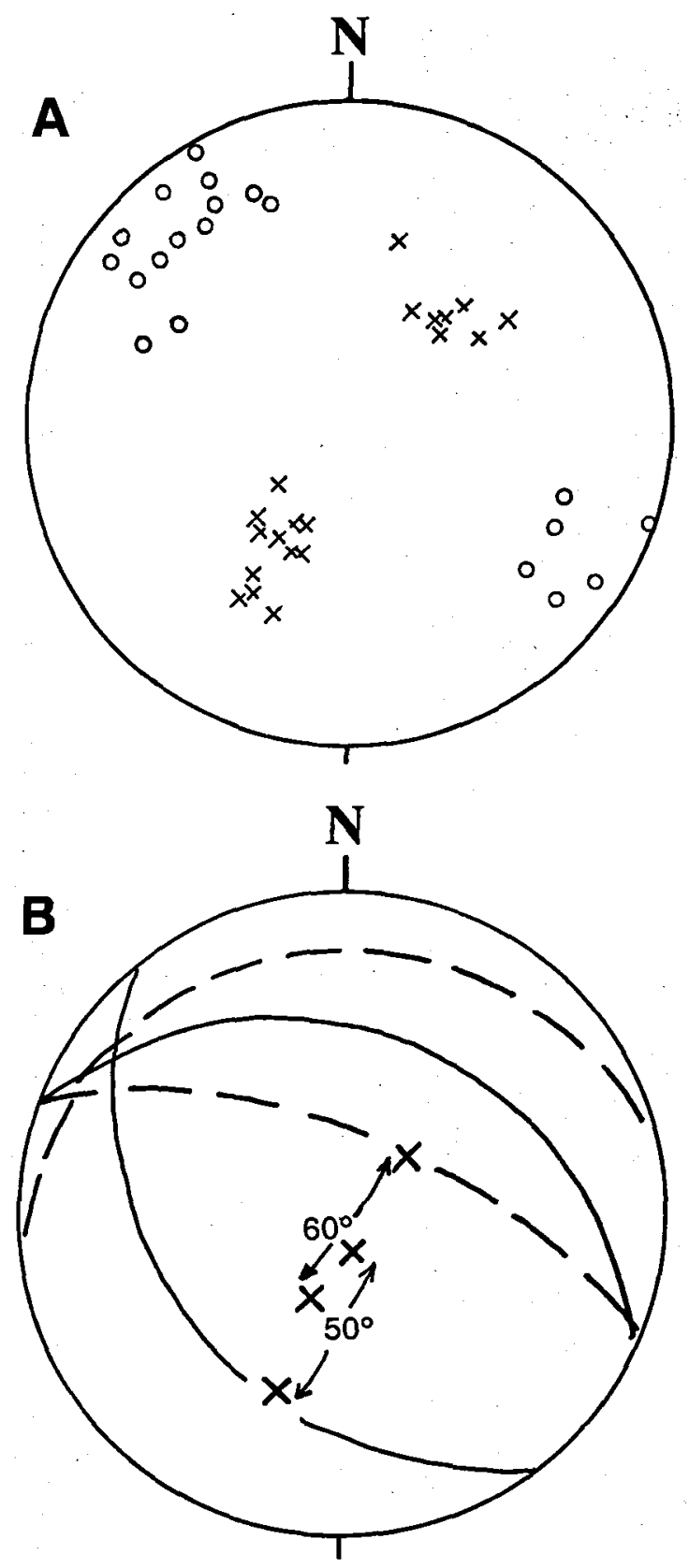

Fig. 4. The orientation of the main directional elements in zone 1. In stereogram $A$ fold axes are indicated by circles and poles to bedding are plotted with crosses. In stereogram $\mathrm{B}$ two sets of conjugate faults are shown. Solid lines are a set with horizontal intersecting bedding, the dashed lines are conjugate faults on northerly dipping fold limb. Crosses are poles to planes. The stereograms are projections of lower hemisphere here and in the following stereograms. series of uniformly laminated dark and light grey clay, silt and fine sand in southern part of the profile. Here it contains approximately 50 varves each about $5 \mathrm{~cm}$ thick (Fig. 3). The beds are dated by the thermo-luminicence (TL) method to be 19.700 years old (Hundahl 1994).

The varves are characteristically folded into chevron or kink folds with a rather constant acute angle close to $60^{\circ}$. In the recumbent syncline south of the ramp some of the disturbances along the inverted limb may be interpreted as syntectonical mudflow and landslide infill along the northern edge of the lake represented by the varve sequence. In the northern part of the profile a unit of glaciofluvial sand and gravel occupies the stratigraphical level of the glaciolacustrine unit. Largescale trough cross-bedding and normal grading are rarely preserved in the intensely deformed layers (Fig. $3)$. The glaciola-custrine unit is truncated by a glaciotectonic unconformity. The glaciolacustrine and glaciofluvial unit is interpreted as representing a lake and a connected system of melt-water streams in front of an ice margin. The varve sequence in zone 1 may represent a foreland depression in front of the initial thrust fault ramping in zone 2 .

Till unit T3. The uppermost unit in the Feggeklit profile is the till T3, which discordantly overlies all the older deposits. The till is an undisturbed, 1-2 m thick red-brown, slightly sandy till, with a high content of erratic stones and boulders, including a relatively high number of indicator stones and boulders from the Oslo region (Larvikite and rhombporphyry). The third glaciodynamic sequence is bounded by the erosional unconformity at the base of the glacio-lacustrine unit and by the erosional surface above till T3. The glaciodynamic sequence includes a glaciotectonic unconformity and a related diatomite glacitectonite. This glacitectonite appears as a cataclastic breccia at the sole of T3 (Fig. 3). The third glaciodynamic sequence was formed during the Late Weichselian glacial advance of the Scandinavian ice shield from Norway to the Main Stationary Line in northern part of Central Jutland (Gry 1940, Pedersen 1993).

\section{Structural architecture}

A fundamental system in the description of structural architecture is to recognize a zonal division based on the degree of complexity. Since the complexity is increasing from the foreland to the hinterland, zone 1 is typically defined to be the zone in the fringe of the undisturbed foreland. The succeeding zones are consequently defined due to a zonal division related to a distal - proximal concept.

At Feggeklit the foreland is situated to the south, and three zones may be differentiated. The foreland of the glaciotectonic complex at Feggeklit is not exposed, but it is inferred to be situated about $200 \mathrm{~m}$ south of the 


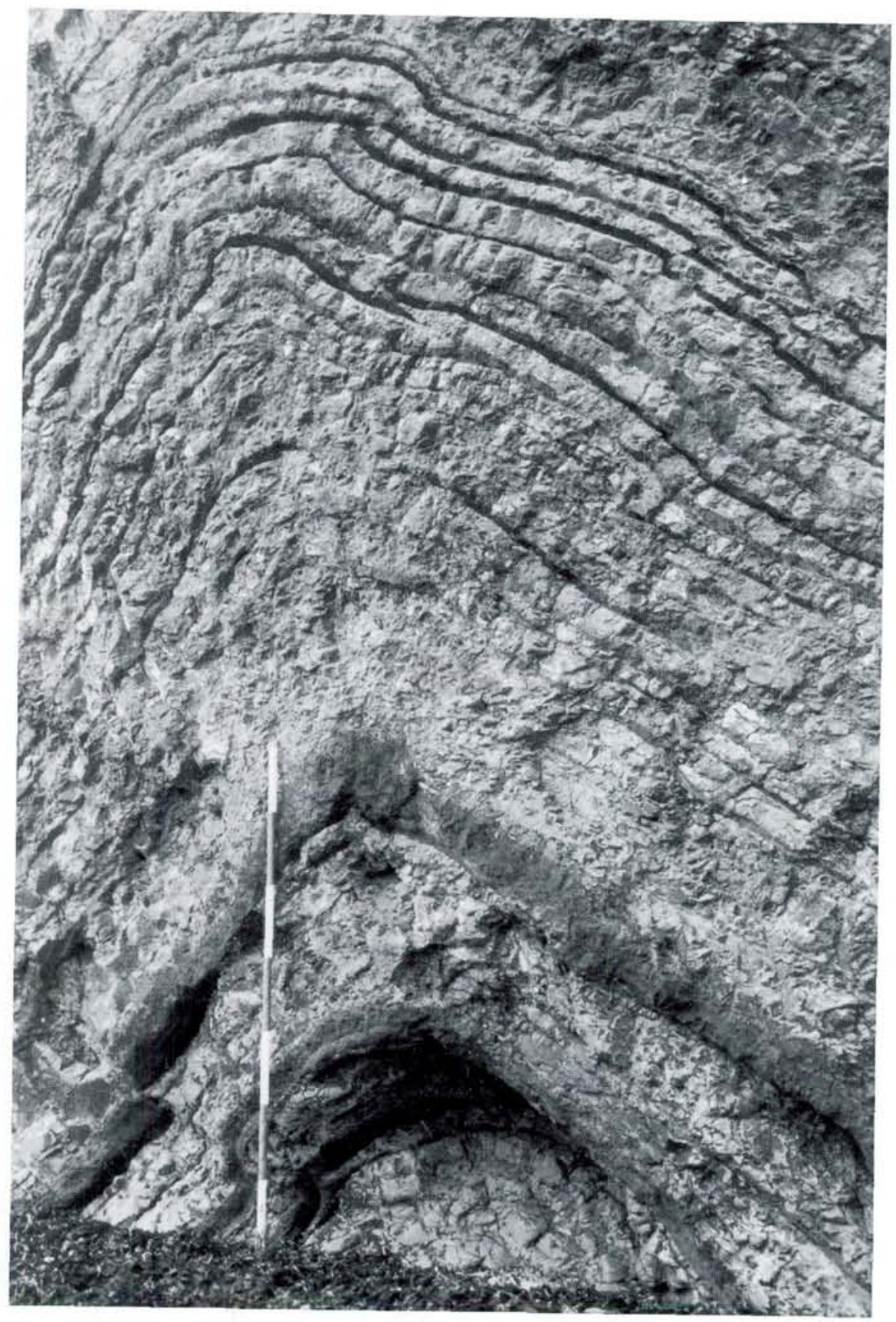

Fig. 5. Angular fold exposed at $150 \mathrm{~m}$ in the Feggeklit profile. The thick dark bed situated near the top of the pole is ash layer +79 . Note the small scale compressional faults on the right limb of the fold which bended parts of the conjugate fault system. The scale on the pole in this photo and in the following photos is $20 \mathrm{~cm}$.

southern limit of the cross section. Thus zone 1 is the distal, zone 2 the intermediate, and zone 3 the proximal zone in relation to the dynamic direction of glacier advance from the north to the south. Zone 2 is between $300 \mathrm{~m}$ and $500 \mathrm{~m}$, and zone 3 occupies the northern end of the profile from $500 \mathrm{~m}$ to the end of the cross section (Fig. 1).

\section{Zone 1}

Zone 1 extends from about $200 \mathrm{~m}$ south of the cliff section to approximately $300 \mathrm{~m}$ inthe profile (Fig. 1). The southern part of the zone is only visible along the shore in calm weather under high pressure conditions when the water table in the western part of the Limfjord may be sufficiently lowered. Zone 1 constitutes the marginal syn- and antiforms adjacent to the undisturbed 
foreland. The wave length of these large scale folds is c. $200 \mathrm{~m}$ and the amplitude is c. $25 \mathrm{~m}$.

On the large scale structures a number of minor parasitic folds occur. In the diatomite and ash layers the fold style is open to close buckle folds with a tendency towards flat topped anticlines. The folds are mainly upright with steep axial planes. The axial planes become more inclined towards the north in the northern part of the zone. The fold axes are generally plunging slightly towards the NNW almost perpendicular to the profile line (Fig. 4). The angular anticline at $150 \mathrm{~m}$ represent one of the large parasitic folds. The amplitude of this angular fold is about $10 \mathrm{~m}$, and the wave length is ca. $25 \mathrm{~m}$ (Fig. 5 ).

Conjugate faults are seen with displacements of $0.1-$ $1 \mathrm{~m}$ (Fig. 6). Related to the conjugate faults the ash layers display box folds (Fig. 7). The intersectional plane of the acute angle of the conjugate fault system is parallel to bedding. The conjugate faults are folded together with the beds (Fig. 6). Some of the box folds

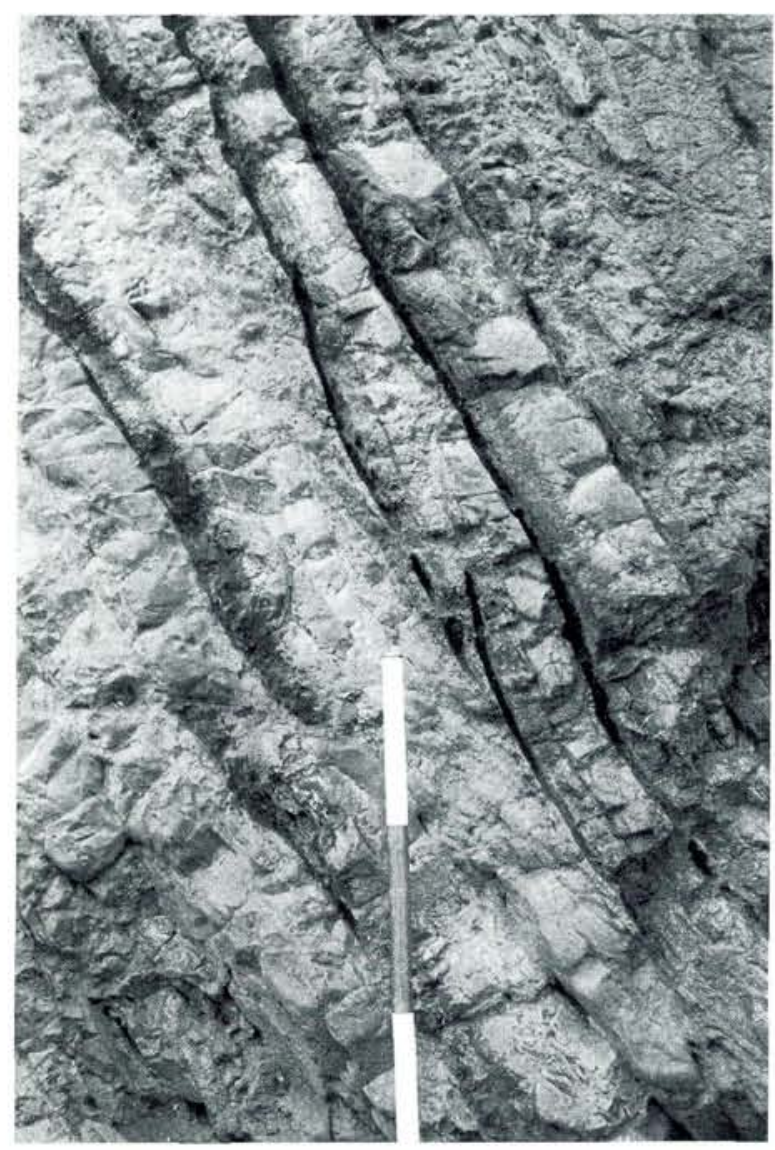

Fig. 6. Conjugate faults occuring on the northern limb of the anticline at $150 \mathrm{~m}$ in the Feggeklit profile (Fig. 1). The intersectional plane for the conjugate faults is parallel to the bedding which has been folded at a later stage of lateral compressional deformation. may be asymmetric due to a preferred displacement along the northerly dipping reverse faults (Fig. 8).

Joints are typical features in zone 1. Anastomosing joints are especially well developed beneath ash layer +101 which is part of a cemented horizon (Fig. 9). The anastomosing joints form a low angle dense framework with the intersectional angle of the acute angle parallel to bedding (Fig. 4). The anastomosing joints are folded together with the beds, proving they are an early stage of deformation. The anastomosing joints are early formed without noticeable displacement. In the development of fractures, the anastomosing jointing changes into higher angle conjugate fractures with displacement along the fracture surfaces.

In the synform structures in the northern part of zone 1 the Feggeklit glacigene group is best represented. The various glacigene sediments here show marked differences in deformation style due to the properties of the individual lithologies. The tills are homogeneous and are deformed very irregularly. Flow and slump-like structures are present, and no discontinuities are present, thus the tills are interpreted to have been watersaturated prior to the deformation. This enabled them to behave with nearly intrusive mobility during the folding. In contrast the glaciolacustrine well-laminated sediments are typically kink folded with folds overturned to the south. The angle between the fold limbs is near $60^{\circ}$, and the length of the limbs are 30 to $50 \mathrm{~cm}$ (Fig. 10). These angular folds are considered to be formed due to the main compressional deformation of the uniformly bedded layers as described by Ramsay (1967, chapter 7.5-7.8) and Davis (1984: 394).

In zone 1 two different types of glacitectonites appear. In the lowermost part of the profile a paraautochthonous glacitectonite is related to the im-placement of the lowermost till unit T1. In the top of the profile an allochthonous glacitectonite is related to the deposition and deformation of the discordant till unit $\mathrm{T} 3$. The diatomite glacitectonite, which develops from the diatomite in the hanging wall anticline in the southern part of zone 2 into the highly altered cataclastic breccia in zone 1, form a type example for the demonstration of the genetic concept of glacitectonites (Pedersen 1988, 1993). The two types of glacitectonite appear in the profile at about $200 \mathrm{~m}$ in Fig. 1.

The transition from zone 1 to zone 2 is marked by the footwall syncline in front of the major ramp thrust between point $300 \mathrm{~m}$ and $350 \mathrm{~m}$ in the profile (Fig. 1). The vertical bedding at about $320 \mathrm{~m}$ forms the northern limb of the footwall syncline whereas the southern limb is irregularly ondulated where it passes into the flat lying synform to the south. 

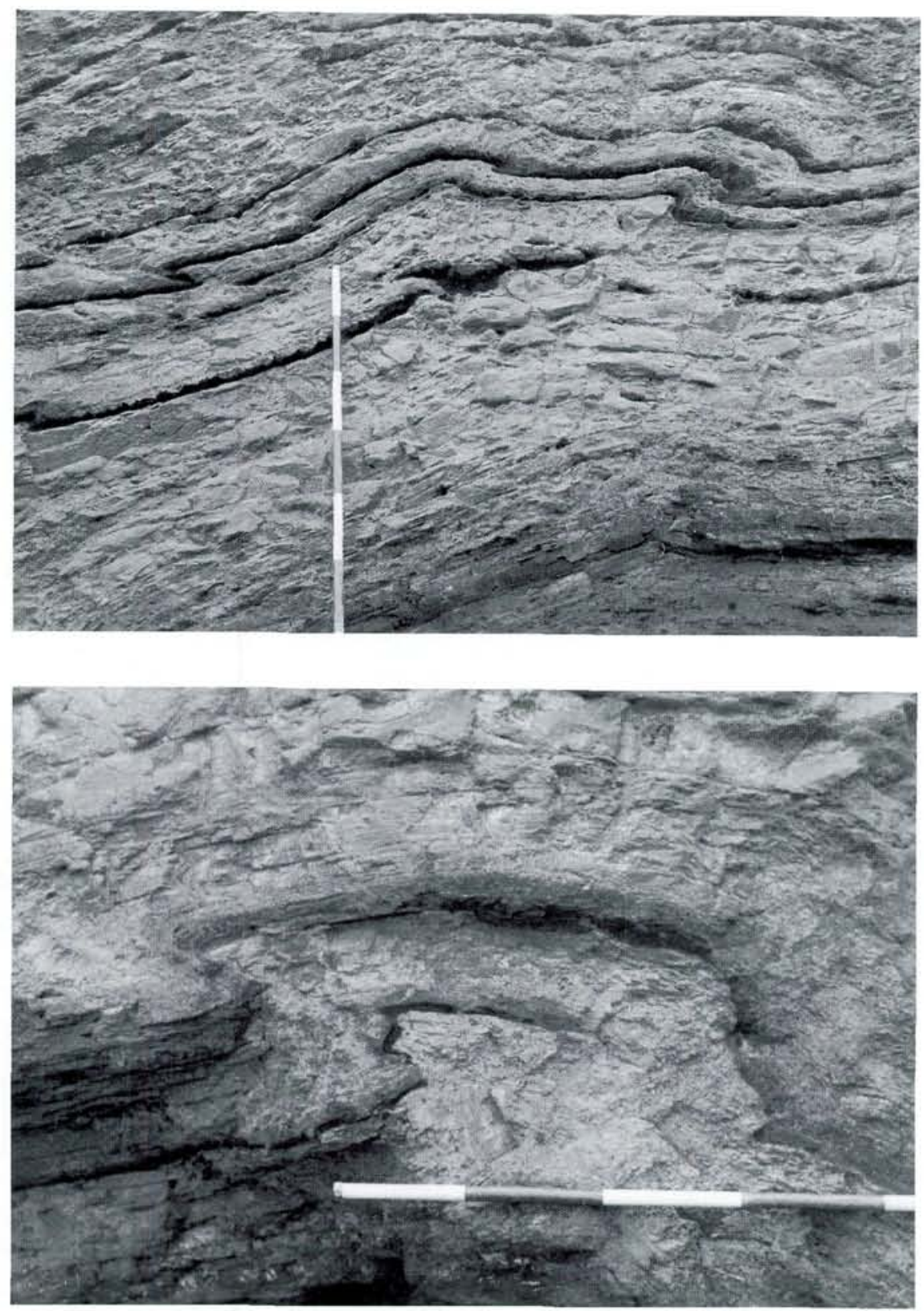

Fig. 7. Box-fold developed due to lateral compressional deformation. The box-folds and the conjugate faults are regarded to represent the same glaciotectonic phase preceeding the phase of buckle folding.
Fig. 8. Asymmetric box fold developed in relation to a conjugate fault system where the northerly dipping reverse fault has taken over the increased displacement. Structure exposed at $135 \mathrm{~m}$ in the profile Fig. 1.

\section{Zone 2}

The important feature in zone 2 is the thrust fault ramp and the related structural elements (located at about 325 $\mathrm{m}$ in Fig. 1). The thrust sheet displaced along the ramp is $50 \mathrm{~m}$ thick and constitutes $40 \mathrm{~m}$ diatomite with ash layers and $10 \mathrm{~m}$ of badly exposed Quaternary sediments. The vertical displacement along the thrust fault is about $20 \mathrm{~m}$ and the horisontal displacement is at least $25 \mathrm{~m}$. The ash layers -13 to -11 are nearly parallel to the thrust fault, thus representing a hanging wall flat. The thrust fault cuts the vertical oriented northern limb of the foot wall syncline and is thus also a foot wall ramp. The thrust fault strikes $124^{\circ}$ and dips $38^{\circ}$ to the NNE. A groove mark striation on the polished thrust surface is plun-ging $38^{\circ}$ towards $12^{\circ}$, nearly perpendicular to the strike (Fig. 11). The striation was formed by small cataclastic grains sheared up along the thrust surface. The vertical layers below the thrust strike $104^{\circ}$, which indicate a minor rotation of the structures. Below the thrust a number of small reverse faults displace the steeply inclined ash layers in the uppermost part of the 
diatomite. About $25 \mathrm{~m}$ north of the ramp the thrust sheet is bent in a monocline thrust fault fold. The northern boundary of zone 2 is marked by the reverse fault at $430 \mathrm{~m}$. This fault is steeply dipping towards the SW and is regarded as an antithetic conjugated fault to the main thrust fault. Thus zone 2 forms a large scale popup structure bounded by the thrust ramp to the south and the antithetic reverse fault to the north.

In zone 2 conjugate faults and box folds appear (Fig. 12) which are interpreted as contemporaneous with the high angle conjugate faults and box folds in zone 1 . The faults were subsequently folded, which indicates that they were formed in an early stage of the progressive deformation. At $400 \mathrm{~m}$ a thrust fault splay cut the fold structure. The splay faults are distinguished from the conjugate faults by their listric geometry, and they are not affected by later deformation. The orientations of the structures which occur in zone 2 are shown in Fig. 11.

\section{Zone 3}

The structures characteristic of zone 3 is low-angle thrusts (Fig. 13) and thrust fault splays (Fig. 14). At $500 \mathrm{~m}$ a listric thrust splay zone appear, which displaces the southward turned anticline. Prior to the splay faults the anticline was upright, but due to the displacement the anticline was deformed into a asymmetric fold. Similar thrust fault splays also appear at $560 \mathrm{~m}$ and $650 \mathrm{~m}$. The latter may be regarded as a pop-up structure with a set of antithetic, steeply dipping reverse faults in the northern part of the structure. The orientation of the structural elements are given in the stereogram Fig. 15.

Two normal extensional faults displace the earlier formed structures at $540 \mathrm{~m}$ and $620 \mathrm{~m}$. The fault at 540 $\mathrm{m}$ strikes $160^{\circ}$. This oblique orientation is probably related to a lateral wrench fault displacement during the final deformation. The fault at $620 \mathrm{~m}$ has a strike parallel to the main strike of the thrust faults (Fig. 15).

The northern part of zone 3 is badly exposed. The architectural style is dominated by overturned anticlines associated with inclined parasitic folds. A synform structure occur at about $700 \mathrm{~m}$ in the profile with glaciofluvial sand and gravel deposited above till T2. The synform is displaced by a thrust fault with a displacement of about $5 \mathrm{~m}$. The fault plane of this thrust has been subjected to the latest stage of overturned folding. In the front of the hanging wall anticline the diatomite is deformed into a glacitectonite.

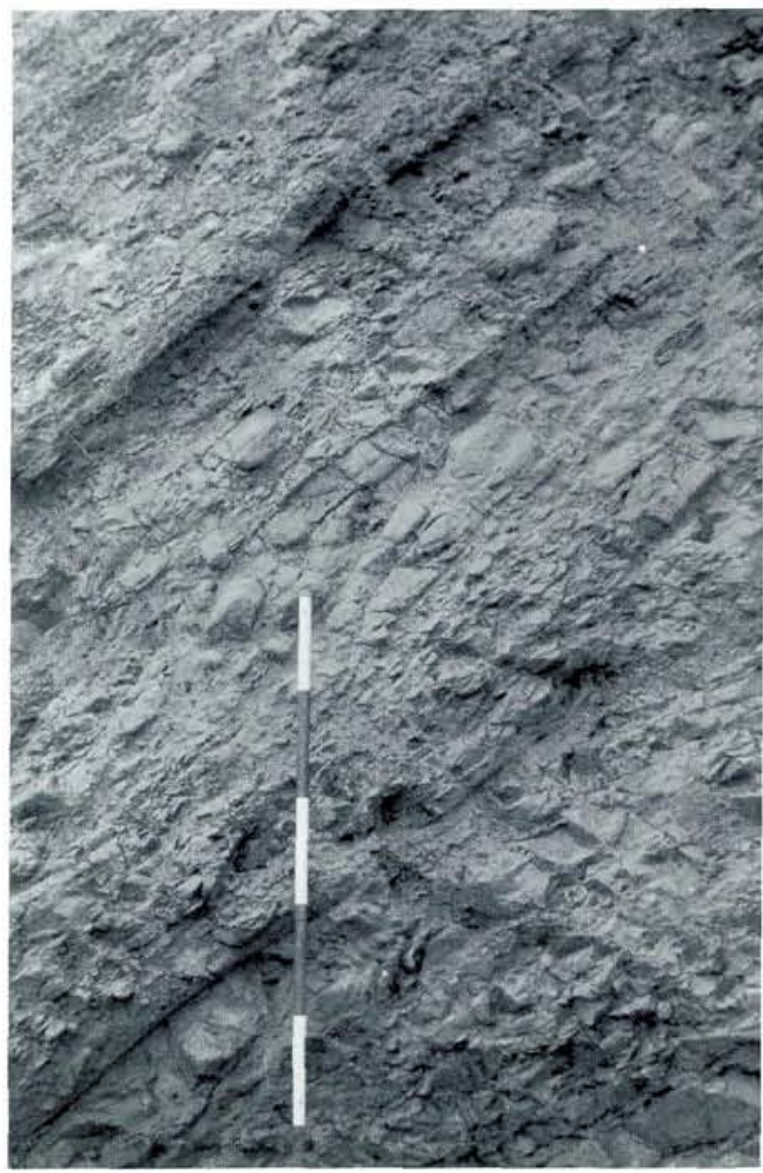

Fig. 9. Anastomosing jointing strongly developed in the diatomite below ash layer +101 . This jointing is interpreted as an early phase of lateral contractional deformation caused by the progressional gravity spreading forces related to the ice advance. Note the reorientation of the joints due to a later phase of folding.

\section{Balanced cross section}

The concept of balanced cross section was introduced by Dahlström (1969) and applied in the structural analysis of foreland folding of the Canadian Rocky Mountains. The fundamental exercise in balanced cross section is to reconstruct the original position of beds prior to the deformation. Dahlström (1969) defined the pin point which is a fixed marker from where the compressionally deformed package of rocks is dragged back to their horisontal, undeformed stage.

The method is supplemented by including calculation of areas, and in the construction of structural cross sections the calculation of the conserved volumes in the deformed and the reconstructed sections helps to verify and test the interpretation of the subsurface geometry of folds and thrust faults. 


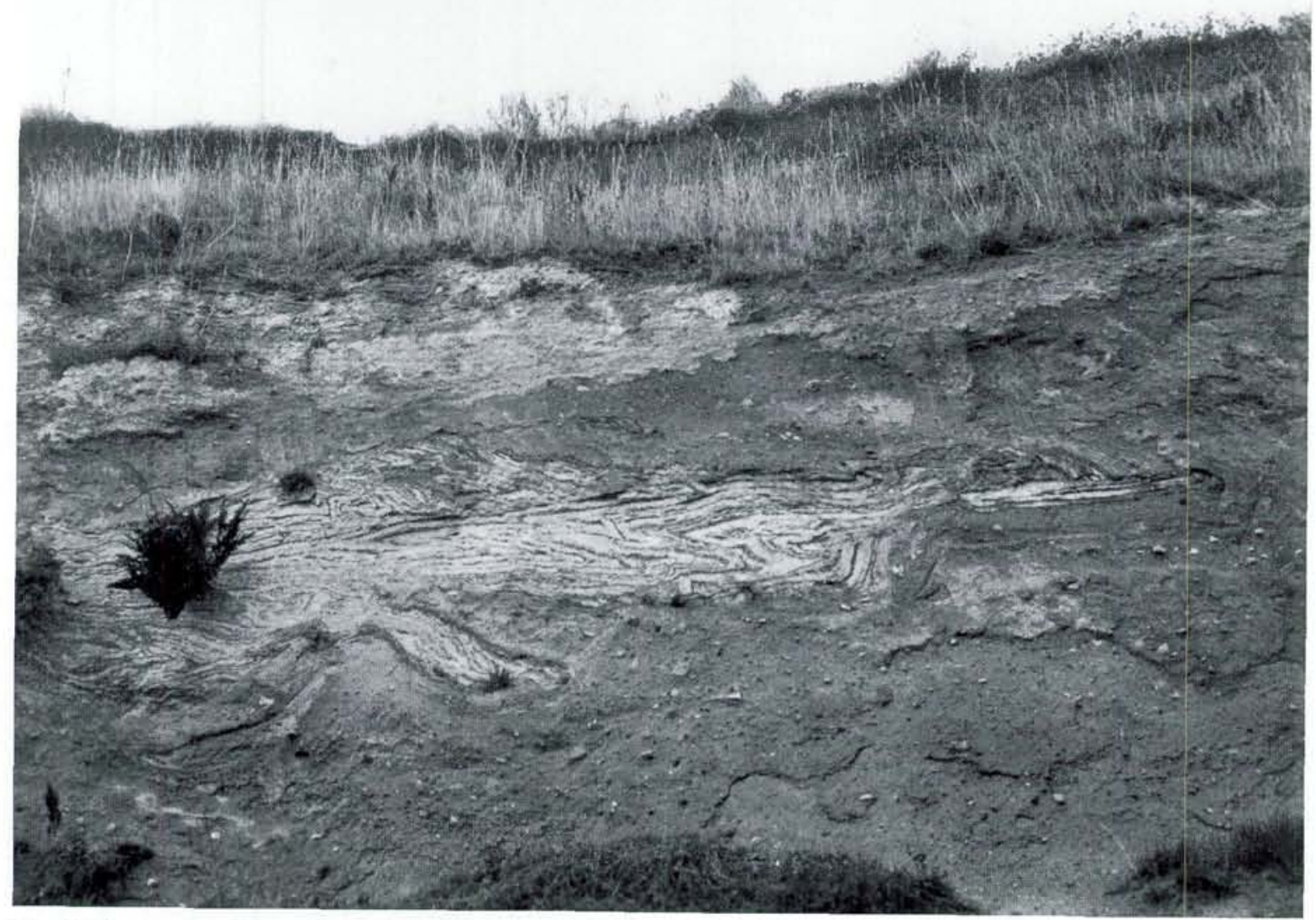

Fig. 10. Contrast in deformation style between the angular folded glaciolacustrine beds and the homogene till unit T2. At the top of the exposure just below the grass the allochthonous diatomite-glacitectonite appears.

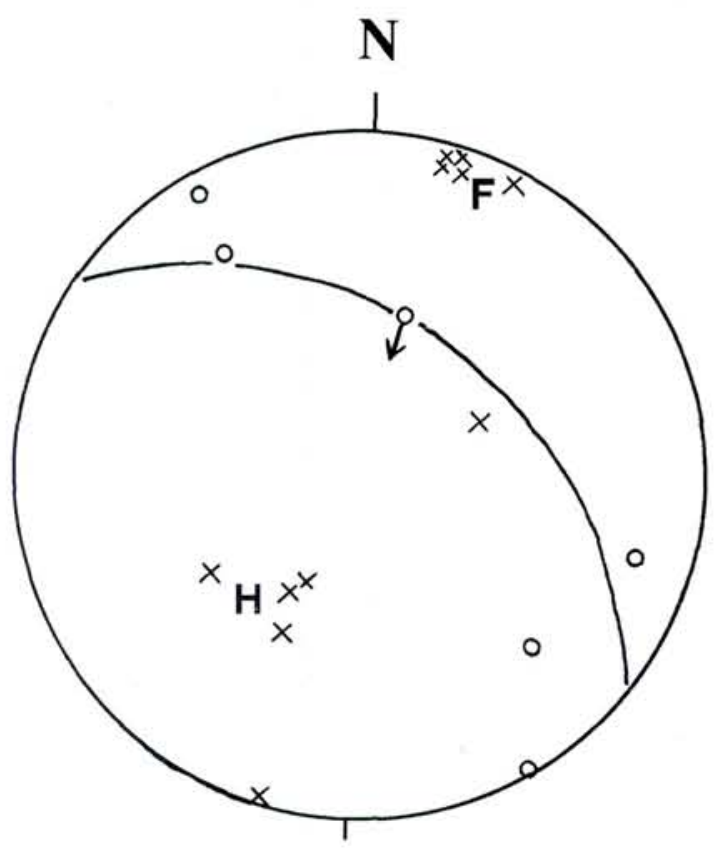

The line balance

The shortening of the structural profile is calculated from the formula:

$\mathrm{e}=\frac{\mathrm{L}_{1}-\mathrm{L}_{0}}{\mathrm{~L}_{0}}$

where $L_{0}$ is the length of an undeformed marker bed measured along the bed in the profile between two identified points, and $\mathrm{L}_{\mathrm{b}}$ is the horisontal distance of the area occupied by the deformed beds, the shortening distance. This is measured in the structural profile between the two identified points (see Fig. 16).

The shortening in the Feggeklit profile has been calculated in two steps. First the calculation has been car-

Fig. 11. Stereogram presenting the orientation of structures related to zone 2 . The great circle in solid line is the thrust fault ramp, circles are fold axes, and the circle with the arrow represent the orientation of the groove mark striation. Crosses are poles to bedding of the hanging wall $(\mathrm{H})$ and the foot wall $(\mathrm{F})$, respectively. 
Fig. 12. A characteristic box fold appearing near the monoclinal thrust sheet bend in zone 2 ( $365 \mathrm{~m}$ in Fig. 1). The box fold formed during the initial deformation phase is characterized by high angle conjugate faulting prior to the folding.

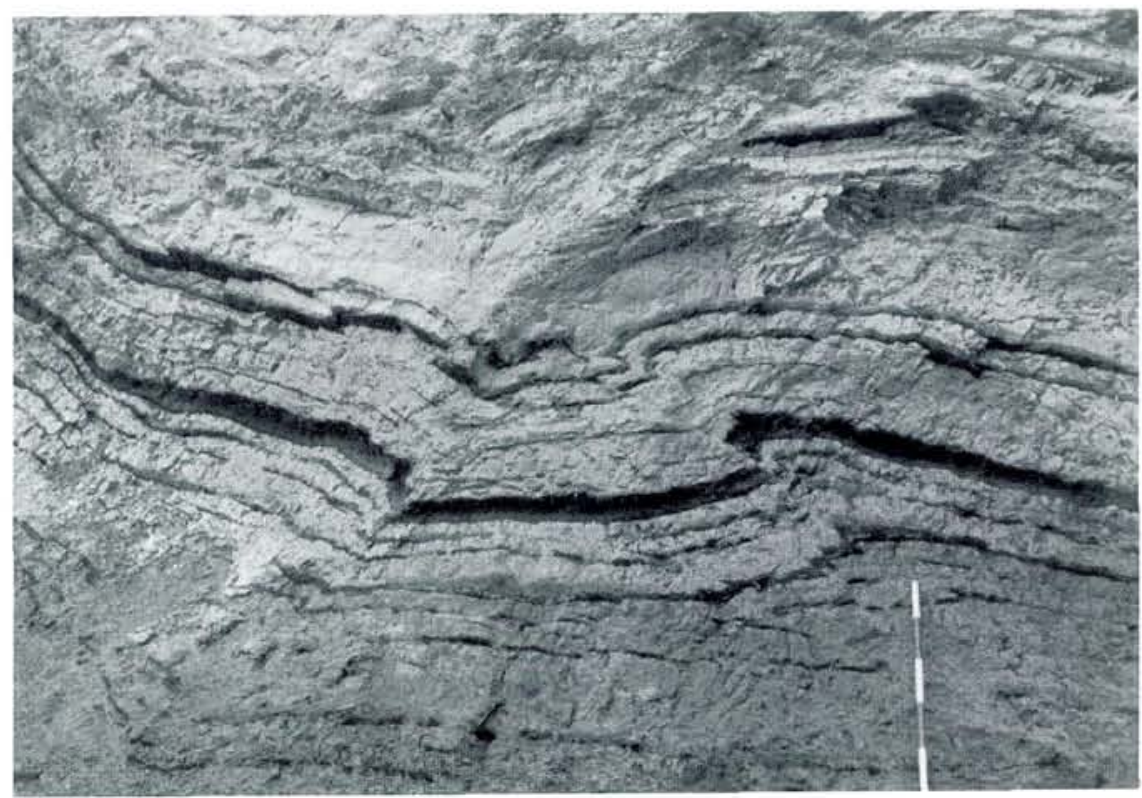

Fig. 13. Low angle thrust ramps form a marked architectural element in zone 3 . Frequently the thrust ramps develop into bedding parallel flats and fades out into the jointet diatomite in between the uppermost ash layers of the Fur Formation.

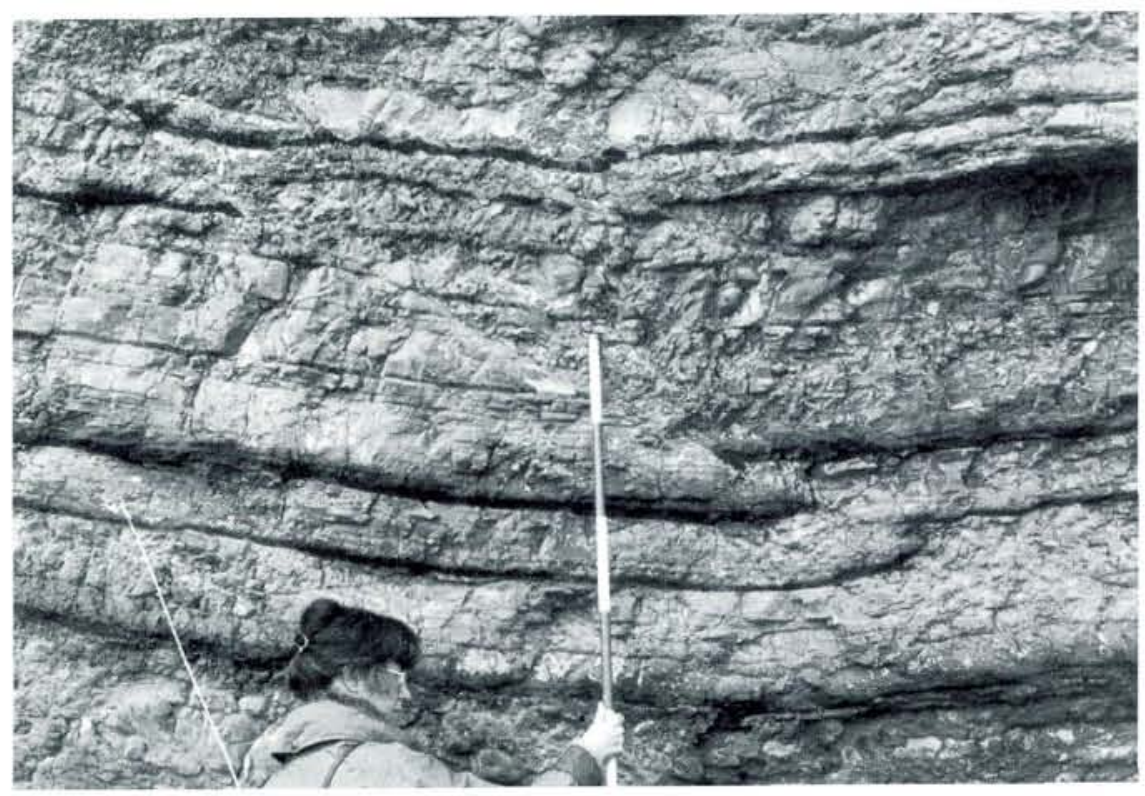

ried out for the folded structures of zone 1 which is regarded to form a reasonable continous fold function. Secondly an attempt has been made to do it for the intier profile with an interpreted overturned anticline to compensate for the discontinuity introduced by the central thrust ramp in zone 2 . The shortening in the fold structure in zone 1 is $10.2 \%$, and for the whole profile the shortening is calculated to $10.9 \%$.

The measurements are taken along ash beds +79 , +101 and +118 . The deviation due to the spreading in fold axis direction is calculated to be $+/-5 \%$ which is the magnitude of uncertainty in all the constructions carried out on the profile.

The areal balance

From the calculation of the volume involved in the deformation it is possible to give an estimate of the depth to the decollement surface for the deformation. The assumptions for this calculation are: 1) that the volume of a block regarded remained constant before and after 


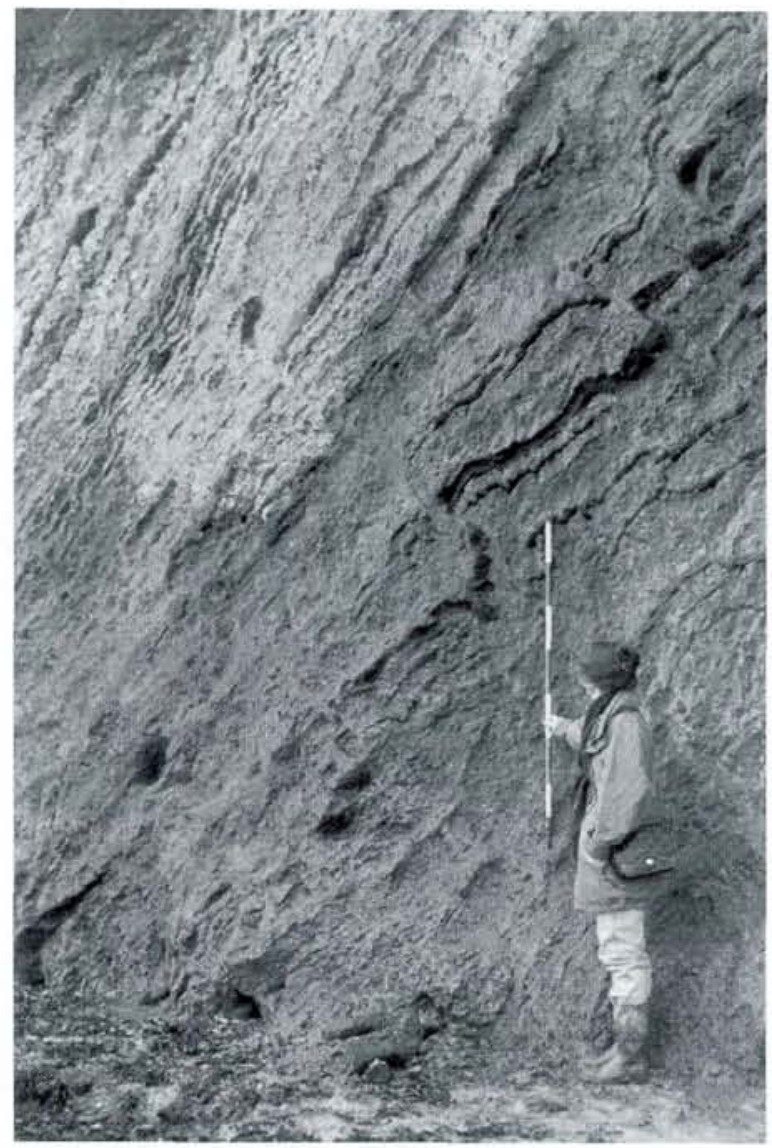

Fig. 14. The listric thrust splay zone which displace the limb of the southward turned anticline situated at $500 \mathrm{~m}$ in the Feggeklit profile.

the deformation (the conservation of volume), 2) the lower boundary of the deformed block is a decollement surface, and 3) no displacement appear including simple shear deformation internally in the block. In the following the assumption of conservation of volume is reduced to conservation of area which may be directly related to the cross section. If we then consider the area below an anticlinal structure $\left(\mathrm{A}_{\text {anticline }}\right.$ ) to be equalent to the volume of the block representing the shortening $\left(\mathrm{A}_{\text {chorrenin }}\right)$ the depth of decollement surface may be calculated from the equations (Fig. 16):

$\int \mathrm{A}_{\text {anticline }}=\mathrm{A}_{\text {shonening, }}$, and $\mathrm{A}_{\text {anticline }}=\int \mathrm{f}(\mathrm{x}) \mathrm{dx}$,

where $f(x)$ is the function describing the curve of the anticlinal structure. This implies that

$\int f(x) d x=\left(L_{1}-L_{0}\right) \times h$.

The area below the anticlinal structure

$\left(A_{\text {anticline }}=\int f(x) d x\right)$

is also called the area of structural relief (Suppe 1985), and it is measured with a planimeter. The distance $\left(\mathrm{L}_{1}-\right.$
$\mathrm{L}_{0}$ ) is given from the line balance. Thus the depth to the decollement surface $(h)$ is given by the equation:

$\mathrm{h}=\frac{\mathrm{A}_{\text {antidine }}}{\left(\mathrm{L}_{1}-\mathrm{L}_{0}\right)}$

The calculation was first carried out for the anticlinal structure in zone 1. As the "regional" reference linie ash layer +118 has been chosen since it was the best defined marker bed in the top of the ash layers in the Silstrup Member. This resulted in a depth to the decollement surface of $80 \mathrm{~m}$. The second calculation involved the whole structural profile including the interpreted anticlinal continuation above the central thrust ramp in zone 2 resulted in a depth of $106 \mathrm{~m}$ to the decollement surface (Fig. 16).

\section{The retrodeformation}

The second calculation is encumbered with some uncertainty, but nevertheless it may represent a deeper position of the decollement surface in the northern part of the profile. An interpretation of this could be that the decollement surface is dipping towards the north. This interpretation is included in the retrodeformation. This interpretation corresponds to the common known geometry of the thrust fault splays below fold structures

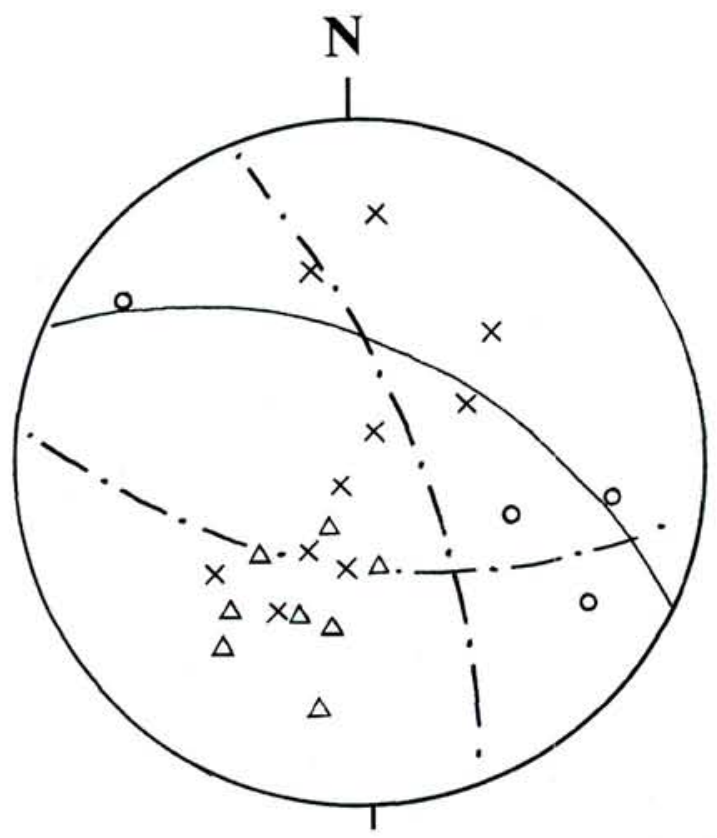

Fig. 15. Stereogram displaying the orientation of structures in zone 3. Solid line represent the main orientation of the listric thrust faults. The triangles are poles to the listric thrust faults measured in different locations on the fault surfaces. Crosses are poles to bedding, circles are fold axes, and the dash and dot lines are normal faults. 

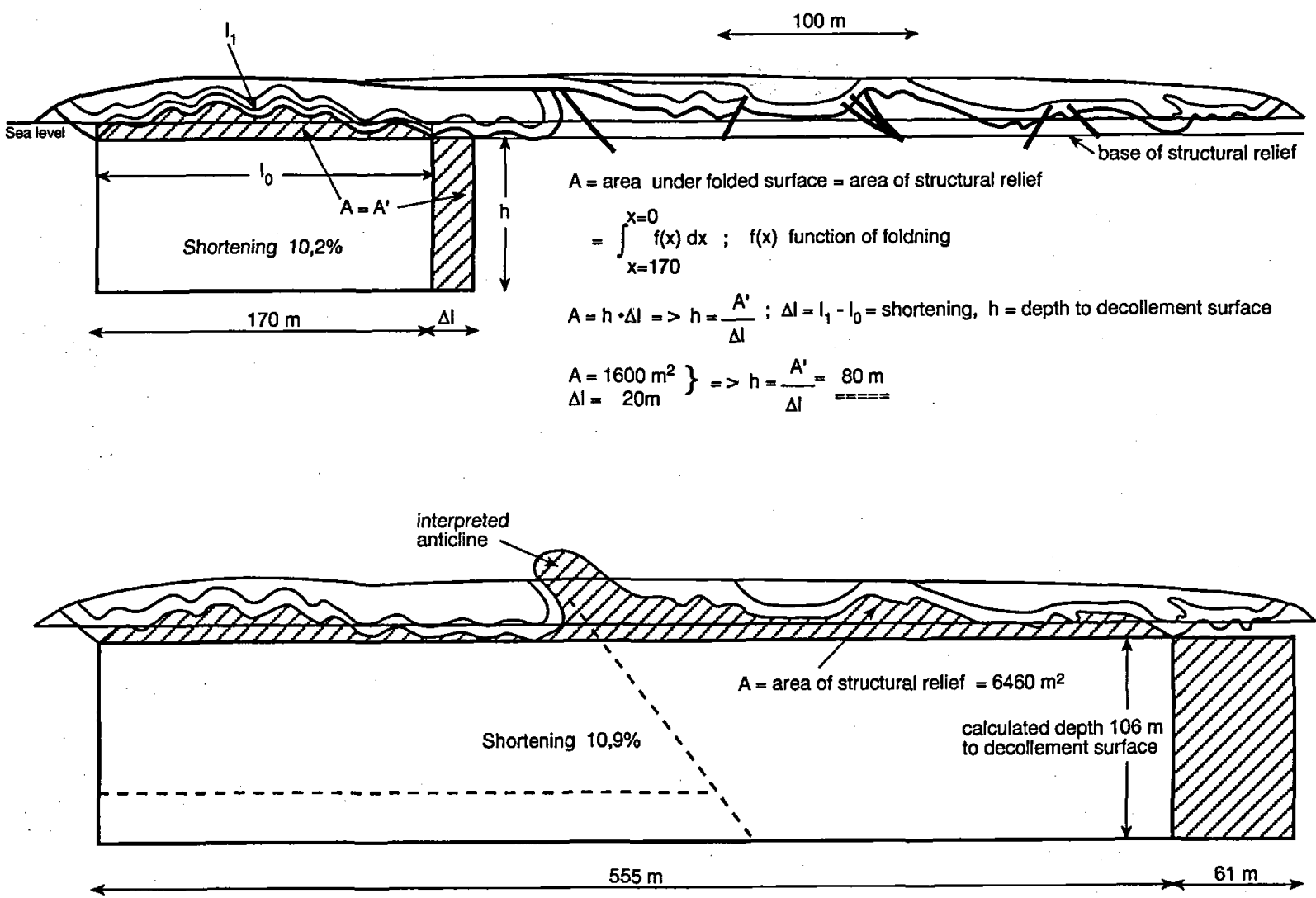

Fig. 16. Demonstration of the calculation of the depth to the decollement surface. In the upper part of the figure the areal balance is applied for the calculation only including the antiformal fold structure in the southern part of zone 1 . In the lower part the areal balance includes the northern part of the profile as well. Here the assumption is made that the antiform above the thrust ramp may be interpreted as indicated in the figure.

in a thin skinned thrust fault complex. The folding at the surface develops into thrust faulting towards the depth, and the thrust fault framework corresponds to an imbricate fan with listric thrust faults heading from a low position of the detachment in the proximal part of the complex to a surface near position in the distal part (Jessen 1931, Gry 1940, Pedersen 1987).

The depth to the decollement surface is thus calculated and interpreted to be $80-100 \mathrm{~m}$ below ash layer +118 . In Fig. 17 the reconstruction of the profile is shown, and the interpretation of the deformation structures below the sea level is constructed due to the assumptions from the calculation.

There appear to be a very good correspondance between the depth of the decollement surface and the stratigraphical position of the most suitable lithology for sliding, namely the Holmehus Formation consisting exclusively of bentonite. The drill investigation carried out by Pedersen \& Petersen (1986) also recorded a single horizon of smectite rich clay in the lowermost part of the Fur Formation. This unit may also have acted as a suitable decollement level which may have facili- tated a shift from a deep position of the decollement surface to the north to a more shallow detach-ment to the south.

\section{Structural phases in the glaciotectonic unit}

Five structural phases are recognized in the glacio-tectonic unit related to the last glaciodynamic event affecting the Feggeklit complex. The first four phases are characterised by gravity spreading deformations related to the proglacial regime. The shift from phase 4 to 5 is marked by a change in structural regimes from proglacial to subglacial, and the structures formed in phase 5 are related to shear deformation and loading beneath the glacier.

The development of the structural phases may be regarded as succesive stages in either time or space. If a fixed volume of the profile is regarded the successive phases developed as a time sequence. Alternatively the structures could be regarded at a fixed time at which 

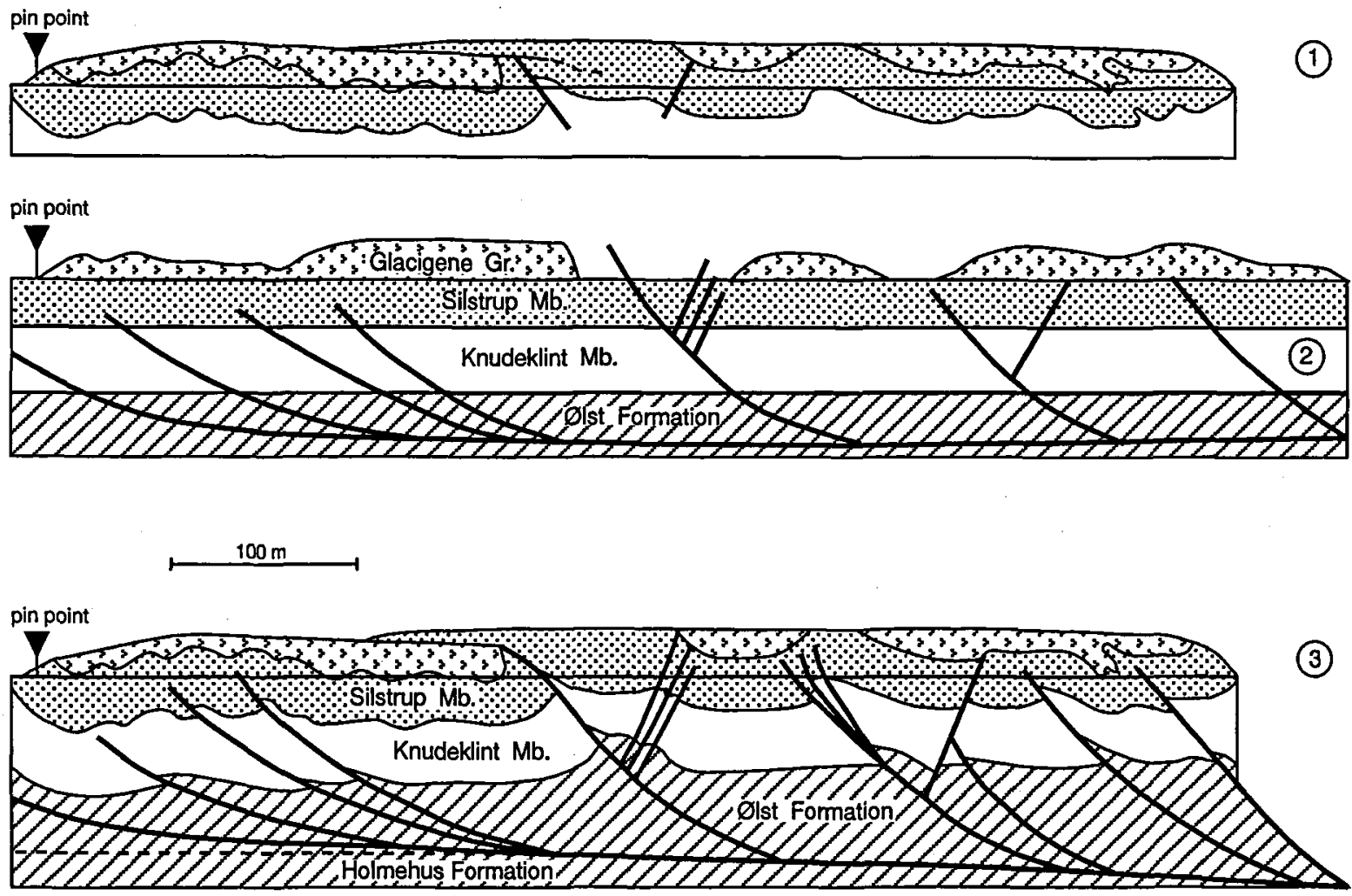

Fig. 17. Balancing and retrodeformation of the Feggeklint profile. 1) is the structural cross section with the pin point defined at the southern limit of the profile. 2) is the stretched profile with the interpreted stratigraphical units situated below the exposed profile. Due to the calculation of the decollement surface and the interpretation of a listric shape of the thrust fractures the thrust faults are indicated. 3 ) is the final deformed profile with the included shortening and the displacement along the thrust ramp and the inferred thrusts and antithetic faults. Note that only the thrust faults known to penetrate all of the Fur Formation is drawn up to the stratigraphical boundary between the Fur Formation and the Feggeklit glacigene group.

the structures developed in phase 1 were the only features appearing in the distal part of the complex, whereas the proximal part is already affected by both phase 1 and 2 .

Phase 1: The structures related to phase 1 are the anastomosing joints (Fig. 9), which form a characteristic framework of planar cross cutting joints with a low angle relative to bedding. The joints are frequent in certain levels, especially a meter below ash layers +101 and +102 , where they obliterate the primary structures of thin bedded ash layers in the diatomite. The acute angle between the joints is about $30^{\circ}$, and the intersectional plane is parallel to bedding. Small joints perpendicular to the intersectional plane occur in the rhomb-shaped joint segments. The anastomosing jointframework is folded with the bedding, and they are also cut by the later faults and thrusts.
Phase 2: The conjugate faults and related box folds are dominating structures formed in phase 2 . The conjugate faults have an acute angle between $50^{\circ}$ and $80^{\circ}$ (Figs 4, 6, 7 and 12). The intersectional plane of the acute angle is parallel to bedding thus indicating a lateral deformation pressure rather than a vertical. The conjugate faults are reorientated by the folding, and the listric thrusts splays cut the conjugate faults.

Phase 3: The main folding is related to phase 3 which created buckle folds in the diatomite (Fig. 5). In the southern part of the profile these folds are upright and open. Towards the north the folds get turned to the south and the inter-limb angle becomes smaller. Listric thrustfault splays are related to the folding. These thrust-fault splays die out towards the top of the profile, whereas the displacement along the thrust faults becomes more pronounced towards the lower levels. 
The glacigene sediments are either folded in a plastic, soft sedimentary style of deformation or in the angular style typical for the multi-layered glacio-lacustrine beds (Fig. 10).

Phase 4: The macro scale thrust faulting examplified by the thrust ramp in the central part of the profile is the most important feature developed in phase 4. Furthermore the pop-up structures with associated back thrusting is included in this phase.
Phase 5: The subglacial deformation created the glacitectonite through shear brecciation, and it was discordantly dragged across the structures in zone 2 . The normal extensional faults were formed due to the increased loading by the ice cap.

\section{Discussion of the progressive deformation}

The progressive deformation caused by the gravity spreading of the advancing ice cap comprises the following stages. The initial deformation is anastomosing
Fig. 18. The structural development of fractures related to the progressing glaciotectonic deformation. The first fractures to develop are the anastomosing jointing with no displacement and a small intersectional angle. The second phase of fracturing is the conjugated faulting which have a distinct displacement and a high intersectional angle. The final phase constitutes deep-seated ramp thrusting with maximum angle correlated with a lateral compression. In the figure the fracturing is related to the increasing confining pressure of a prograding deformation. The Mohr diagram shows the relationship between the fracture orientation and the shape of the Mohr envelope.

Fractures P1, P2 and P3 form at angles $12^{\circ}, 25^{\circ}$ and $40^{\circ}$, respectively, to the direction of maximum shear (modified after Hobbs et al. 1976, fig. 7.33).
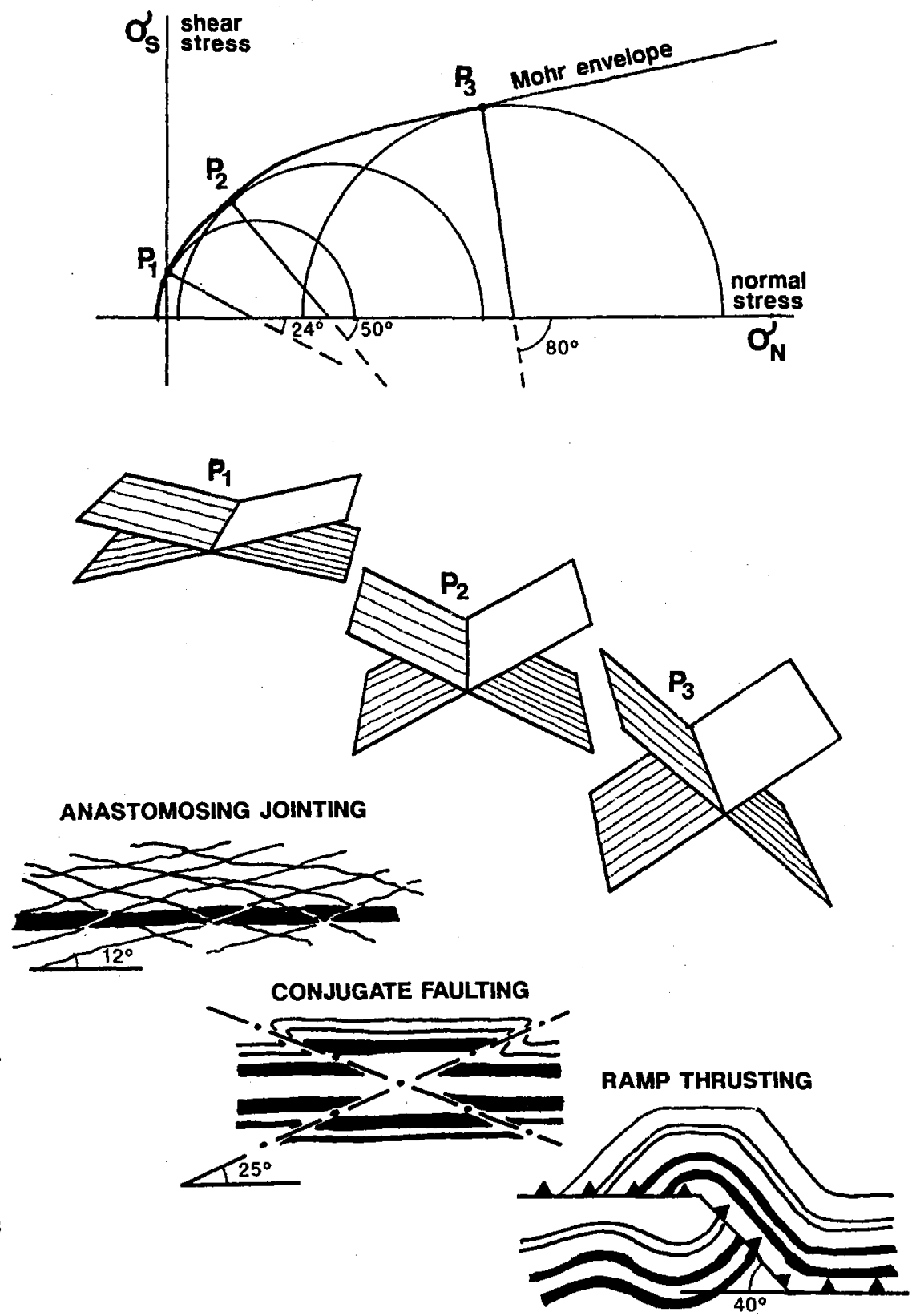
jointing, phase 1 . This low-angle fracturing is penetrative but appears to be best developed in certain stratigraphical levels. The build-up of pore-pressure in different stratigraphical levels determines the generation of anastomosing joints. Pore-pressure is raised due to a combination of lithostatic pressure and loading by the ice cap in the adjacent terrain (i.e. the hinterland). Distinct lithologies have a very low permeability and these assist in the build-up of high pore-water pressure. Thus the laminated diatomite has lower vertical permeability than the structureless diatomite, and the continuous calcareous concretion horizon with ash layers +101 also acted as a seal.

Increasing stress will cause the angle of fracturing to steepen (Hobbs et al. 1976, fig. 7.33) (Fig. 18). In response to this, conjugate faulting developed (phase 2) and created box folding.

In the conjugate fault pair the dominating synthetic fault will be preferred in the further, progressive deformation, which then creates an unequel pair. The progressive growth of the preferred faults results in a pinnate fracture pattern. In the Feggeklit profile this is identical with the listric thrust fault structures, which formed contemporaneously with the folding, and the thrust faulting is regarded as the cause of the folds. The ultimate effect of the progressive build-up of pressure and subsequent fracturing is a steep-angle ramp thrusting. In the profile only one of these steep faults is seen (zone 2). However, the thrusting between $550 \mathrm{~m}$ and $600 \mathrm{~m}$ and around $640 \mathrm{~m}$ to $650 \mathrm{~m}$ in the profile are interpreted as formed contemporaneously, due to the same mechanism.

The final phase in the deformation is related to the transgression of the ice cap over the proglacially formed structures (phase 1 to 4 ). Phase 5 is a subglacial deformation. The glacitectonite is formed, and this lithology is regarded as diagnostic of glacier trans-gression. The ramp fault anticline is dragged along the sole of the glacier to form the glacitectonite discordantly, superposed upon the glacigene sequence (northern part of zone 1). In the most distal part of the sheared-out glacitectonite the diatomite-glacitectonite is altered to diatomite-rich bands mixed into the till at the base of the ice. This continuous development of the glacitectonite was discussed and illustrated by Pedersen (1988: fig. 2), and a set of different stages of glacitectonites is distinguished due to the intensity of shear deformation forming the tectonic breccia.

A set of extensional faults cut the structures in zone 3. These faults developed subsequent to a change in the pressure from a foreland inclined vector to a more vertical directed pressure vector due to the overburden by the ice cap. Consequently the normal faults are regarded as evidence of loading by the ice cap in combination with adjustment to the redistribution of volumes caused by the former thrust faulting.

\section{Discussion of glaciodynamic development}

The large synform in zone 1 is interpreted as formed in the initial stage of deformation situated in front of the ice margin. Here it acted as the site of glacio-lacustrine deposition. The laminated glaciolaustrine sediments are interpreted as varved, and 50 varves are counted. The varves are folded and transgressed by the ice advance of the third glaciodynamic event. This suggests that the glaciotectonic complex was formed within a period of minimum 50 years.

Assuming that the ice margin was situated at the northern end of the profile (about $0.5 \mathrm{~km}$ away from the lake-filled synform) prior to generation of the synform the velocity of the advancing ice was about 10 $\mathrm{m}$ per year.

It is interesting to speculate that the same order of magnitude of velocity may have characterized the ice advance on a more regional scale. The top of the preglacial Skærumhede Series (Bahnson et al. 1974) in the northern part of North Jutland has been dated to 32.000 BP by the C-14 AMS method (Kaj Strand Petersen, written comm. 1995). The pre- to syn-glacial sand in dislocated floes in Lønstrup Klint (Jessen 1931) contain redeposited plant fragments of $29.000+/-2.000$ years BP (Michael Houmark-Nielsen, pers. comm. 1995) indicating a maximum age of the ice advance. Hundahl (1994) states 20.000 years BP at Feggeklit. A time span in the order of 10.000 years and a distance of $100 \mathrm{~km}$ indicates an average velocity of c. $10 \mathrm{~m}$ per year. This velocity corresponds fairly well with velocities of recent ice caps, e.g. has the ice movements of the marginal part, outside the valley glaciers, of the Inland Ice in central West Greenland been measured to 10-12 m per year (Niels Rhee, pers. comm. 1995).

When the front of the ice approached a certain area an increase in vertical as well as in horizontal compression appeared. Due to this build-up of pressure fractures formed. These formed in the subsurface where the highest pore pressure facilitated fracturing. Subsequent to the formation of fractures displacement occur and faults developed. The level of faulting increased towards the depth according to the increasein confining pressure, and the deepest level affected by the deformation is about $100 \mathrm{~m}$ below the surface. For the deformation at Feggeklit the decollement surface is situated in the bentonite of the Holmehus Formation. This formation is the most obvious lithology for sliding, and it is thus argued that the development of the basic decollement zone for glaciotectonics is primarly dependant on lithology rather than on the depth of permafrost.

\section{Conclusions}

The glaciodynamic analysis of the Feggeklit profile has shown that three glaciodynamic sequences are represented: 
1) The first sequence is of Saalian age and consists of a kineto-stratigraphical unit, the till $\mathrm{T} 1$, and a glaciotectonic unit represented only by an authoch-thonous diatomite-glacitectonite.

2) The second sequence is of Saalian age and comprises only the till $\mathrm{T} 2$ and some erosional remnants of glaciofluvial deposits.

3) The third sequence is of Late Weichselian age and represent the most important glaciodynamic event at Feggeklit. The sequence comprises a kinetostratigraphical unit and a glaciotectonic unit. The kineto-stratigraphical unit consists of the a proglacial glaciolacustrine and -fluvial deposits and the subglacial deposited till T3. The till rests on a tectonic unconformity above a glacitectonite. The glacio-tectonic unit represents the main structural complex at Feggeklit. It includes deformed ash layers and diatomite of the Tertiary Fur Formation as well as the deformed glacigene deposits.

Five glaciotectonic deformation phases are distinguished of which the first four are related to a proglacial regime and the final phase to a subglacial regime:

Phase 1 is characterized by the anastomosing jointing.

Phase 2 is characterized by conjugate faulting.

Phase 3 comprises the main phase of folding and listric thrust faulting in splay fans developed contemporaneous.

Phase 4 includes the thrust faulting along the major ramp connected with back thrusting and formation of pop-up structures.

Phase 5 includes the formation of the glaciotectonic unconformity and the cataclastic brecciation and shear drag of the diatomite-glacitectonite which was formed at the sole of the overlying lodgement till.

The glaciodynamic event related to the third glaciodynamic sequence was caused by the Norwegian Ice advance transgressing northern Jutland from ca. 30.000 to 20.000 years BP. A balanced cross-section of the fold structures indicates that the detachment of the dislocation is situated below the base of the Fur Formation in the plastic clay at a depth of $80-100 \mathrm{~m}$. The velocity of the deforming glacier is estimated to be $10 \mathrm{~m}$ per year. The structures formed during the glaciotectonic phases fits into a model of progressional glaciotectonic deformation.

\section{Acknowledgements}

This paper is the conclusion of glaciotectonic studies formerly presented in the Work Group on Glacial Tectonics (WGGT) under the INQUA Commission on Formation and Properties of Glacial Deposits. I wish to thank colleagues and friends in the WGGT for the stimulating field meetings and workshops. An early draft of this paper was read by Michael Houmark-Nielsen, Birger Larsen and Gunver Krarup Pedersen and I am grateful for their suggestions and critical comments. An anonymyous referee is thanked for critical comments on the structural part of the manuscript. Technical assistance in preparing the Feggeklit cross section was provided by Torben Friis Jensen, DGU.

\section{Dansk sammendrag}

Feggeklit profilet er en enestående lokalitet for studiet af istektonisk deformation. Feggeklit er beliggende nordligst på Mors og tilhører gruppen af lokaliteter, som allerede Gry (1940) beskrev. Formålet med denne artikel er at demonstrere et typeeksempel på progressiv istektonisk deformation.

For at redegøre for denne model er der anvendt et sæt termer, som ikke tidligere har været almindeligt brugt $\mathrm{i}$ Danmark:

1) Glaciodynamisk event: Et regionalt isfremstød karakteriseret ved en ensrettet dynamisk påvirkning. Et glaciodynamisk event er repræsenteret ved en glaciodynamisk sekvens.

2) Glaciodynamisk sekvens: Resultatet af et glaciodynamisk event. Den glaciodynamiske sekvens består både af en aflejringsenhed og en deformationsenhed, henholdsvis en kineto-stratigrafisk enhed og en glacialtektektonisk enhed. Den kineto-stratigrafiske enhed består kun af kvartære glacigene sedimenter, mens den glacialtektoniske enhed omfatter såvel kvartære som prækvartære sedimenter påvirket af en istektonisk deformation.

3) Glacialtektonisk enhed: En bjergartsenhed deformeret af en istektonisk deformation. Bjergarterne er overvejende sedimenter, men konsoliderede bjergarter kan også indgå.

4) Kineto-stratigrafisk enhed: En simpel eller sammensat till enhed, som tillige omfatter en glacialtektonisk breccie og de glaciofluviale sedimenter, der er knyttet til et isfremstød og iskappens tilbagesmeltning (Berthelsen 1978).

5) Glacialtektonisk deformation: Deformation, som tilskrives en prograderende iskappe. Deformationen kan opdeles i mindst to distinkt forskellige faser: 1) 
proglacial foldning og overskydning, og 2) subglacial forskydningsspænding (shearing) som medfører shearfoldning og glacialtektonisk kataklastisk brecciering.

6) Glacialtektoniske faser: Succesive deformationsfaser relateret til en glacialtektonisk deformation. De glacialtektoniske faser er karakteriseret ved specifikke strukturer og deres indbyrdes strukturelle relationer markerer fase-successionen.

7) Glacitektonit: Kataklastisk bjergart dannet ved subglacial deformation (Pedersen 1988). Glacitektoniter kan forekomme i alle grader af omdannelse fra en svag brecciering, typisk af en prækvartær sedimentær bjergart, til en gennemgående udvalsning af en bjergart, som gradvis integreres $i$ en till domineret af lokale intrabassinale elementer.

Lagserien, som er blottet i Feggeklit profilet, består af eocænt moler med askelag tilhørende den $\varnothing \mathrm{vre}$ del af Fur Formation samt en overlejrende serie kvartære glacigene sedimenter.

Den prækvartære stratigrafi, påvirket af den glacialtektoniske deformation, omfatter foruden Fur Formationens Silstrup Led tillige den $\emptyset$ vre del af Knudeklint Led, som erblottet langs sålen af den hængende blok ved overskydningsrampen $i$ den centrale del af profilet. Ud fra tolkningen af deformationsdybden er det desuden sandsynliggjort, at det plastiske ler $i \emptyset l s t$ og Holmehus Formationerne har været påvirket af den glacialtektoniske deformation.

Den kvartære stratigrafi omfatter tre glaciodynamiske sekvenser, som repræsenterer tre glaciodynamiske event.

1) Den første sekvens er af Saale alder og består af en kineto-stratigrafisk enhed, den nedre moræneler, T1, og en glacialtektonisk enhed, som kun er repræsenteret ved en autochton diatomit-glacitektonit beliggende $i$ toppen af Fur Formationen og under den nedre moræneler.

2) Den anden sekvens er af Saale alder og består kun af mellemste moræneler, $\mathrm{T} 2$, og nogle erosionsrester af en glaciofluvial aflejring.

3) Den tredie sekvens er af Sen Weichsel alder og repræsenterer det vigtigste glaciodynamiske event ved Feggeklit.

Sekvensen består af en kineto-stratigrafisk enhed $\mathrm{og}$ en glacialtektonisk enhed. Den kineto-stratigrafiske enhed omfatter en proglacial glaciolacustrin og -fluvial aflejring samt en subglacialt aflejret $\emptyset v$ re moræneler, T3. Den øvre moræneler hviler på en tektonisk unconformitet beliggende oven på en glacitektonit. Den glacialtektoniske enhed repræsenterer det egentlige strukturelle kompleks som er blottet i Feggeklit. Det inkluderer deformerede tertiære askelag i diatomit tilhørende Fur Formation så vel som deformerede glacigene aflejringer. Det grundlæggende system i beskrivelsen af struk- turel arkitektur er opdelingen i zoner baseret på graden af kompleksitet. Da kompleksiteten tiltager fra forlandet mod baglandet, defineres zone 1 typisk som zonen i randen af det uforstyrrede forland. Ved Feggeklit er forlandet beliggende mod syd, og tre zoner kan udskilles. Selve forlandet for det glacial-tektoniske kompleks er ikke blottet, men det antages at være beliggende omkring $200 \mathrm{~m}$ syd for den sydlige begrænsning af profilet. Zone 1 betegner således den distale, zone 2 den intermediære, og zone 3 den proximale zone i forhold til den dynamiske retning af det regionale isfremstød fra nord mod syd. Zone 2 er beliggende mellem $300 \mathrm{~m}$ og $500 \mathrm{~m}$, og zone 3 udgøres af den nordlige del af profilet fra $500 \mathrm{~m}$ til den nordlige ende af profilet (Fig. 1).

Zone 1 består af storskala syn- og antiklinaler med bølgelængde på c. $200 \mathrm{~m}$ og en amplitude på c. $25 \mathrm{~m}$. Et antal mindre parasitfolder forekommer på flankerne af storskala strukturerne. Disse folder fremstår tydeligt i de mørke askelag i diatomiten, hvor foldestilen er repræsenteret ved åbne til tætte opretstående bøjefolder med tendens til fladtoppede antiklinaler.

Konjugerede forkastningen optræder i zone 1 med forsætninger på $0.1-1 \mathrm{~m}$. I tilknytning hertil danner askelagene "box-folder". Vinkelhalveringsplanet for den spidse vinkel mellem de konjugerede forkastninger er parallel med lagdelingen, og de konjugerede forkastninger er foldet sammen med lagdelingen. Nogle boxfolder er asymmetrisk udviklet med en foretrukken forsætning langs med de nordhældende forkastninger i de konjugerede forkastningssæt.

Anastomoserende sprækker forekommer specielt veludviklet under askelag +101 , som er indlejret i en cementsten. De anastomoserende sprækker danner et tæt netværk, hvor vinkelhalveringsplanet for den lille vinkel mellem de konjugerede sprækker er parallel til lagdelingen. De anastomoserende sprækker er også foldet sammen med lagdelingen, men der er ingen lateral forsætning langs sprækkerne.

De glacigene sedimenter i zone 1 viser stor variation i foldestil. Den mellemste moræneler er meget irregulært foldet med slumplignende strukturer uden internt bevaret planaritet, og den tolkes som værende vandmættet umiddelbart f $\emptyset \mathrm{r}$ deformationen. I modsatning hertil er det vellaminerede glacio-lacustrine sediment typisk "chevronfoldet" med folder overkippet mod syd. Vinklen mellem folde-flankerne er nær $60^{\circ}$, hvilket er almindeligt for foldning af lagserier med ensartede lagtykkelser.

To forskellige typer glacitektonit forekommer i zone 1. I den nederste del af profilet er en paraautochton glacitektonit tilknyttet aflejringen af nedre moræneler, T1. I toppen af profilet er en allochton glacitektonit knyttet til aflejringen og deformationen af den diskordante $\emptyset$ vre moræneler, $\mathrm{T} 3$. 
I Zone 2 er det væsentligste strukturelle element den store overskydningsrampe, som forekommer ved 325 $\mathrm{m}$ i profilet (Fig. 1). Skiven, som er opskudt langs rampen, er $50 \mathrm{~m}$ tyk og består af $40 \mathrm{~m}$ diatomit med askelag og $10 \mathrm{~m}$ dårligt blottede, kvartære sedimenter. Den vertikale forsætning langs overskydningen er omkring $20 \mathrm{~m}$, og den horisontale forskydning er mindst $25 \mathrm{~m}$. Den lodretstående flanke af synklinalen i den liggende blok danner overgangen mellem zone 1 og 2 . Overskydningen stryger $124^{\circ}$ og hælder $38^{\circ}$ mod NN $\varnothing$. På den glatpolerede overskydningsflade findes en forskydnings-striation, som dykker $38^{\circ} \bmod 12^{\circ}$, næsten vinkelret på strygningen. De vertikale lag under overskydningen stryger $104^{\circ}$, hvilket antyder en mindre rotation af strukturen. Under overskydningsrampen optræder flere mindre reverse forkastninger, som forsætter de stejltstående askelag i den $\emptyset$ vre del af Fur Formationen.

Omkring $25 \mathrm{~m}$ nord for rampen er overskydningsskiven bøjet i en monoklinal flexur. Den nordlige grænse af zone 2 markeres af den reverse, stejlt sydhældende forkastning ved $430 \mathrm{~m}$. Denne forkastning tolkes som en antithetisk, konjugeret forkastning til den ledende overskydning, og zone 2 betragtes således som en sammenhængende "pop-up" struktur begrænset af en overskydningsrampe mod syd og en antithetisk revers forkastning mod nord.

Zone 3 er karakteriseret ved svagt hældende overskydninger og overskydnings-vifter. Ved $500 \mathrm{~m}$ i profilet forekommer en listrisk overskydningsvifte, som forsætter en sydvergent antiklinal. Før forkastningerne forsatte strukturen, var antiklinalen opret, men på grund af forkastnings-viften blev antiklinalen overkippet mod syd. Lignende strukturer forekommer ved $560 \mathrm{~m}$ og $650 \mathrm{~m}$. Den sidste kan endog betragtes som en pop-up struktur med et sæt af stejlthældende reverse forkastninger i den nordlige del af strukturen.

Den nordligste del af zone 3 domineres af overkippede folder associeret med liggende parasit-folder. Ved $700 \mathrm{~m}$ forekommer en synform med smeltevandssand og -grus aflejret over det mellemste moræneler. Synformen er forsat af en overskydning med en forsætning på omkring $5 \mathrm{~m}$. Denne overskydning er blevet foldet $i$ det seneste stadie af overkippet foldning.

To normalforkastninger forsætter de tidligere dannede strukturer i zone 3 . Den ene forkastning stryger $160^{\circ}$, og den tolkes som dannet ved en skæv forsætning (wrench fault) i slutfasen af deformationen.

Fem glacialtektoniske faser kan adskilles i den glacialtektoniske enhed knyttet til den tredie glaciodynamiske sekvens ved Feggeklit. De første fire faser er knyttet til et proglacialt regime, og den afsluttende fase repræsenterer et subglacialt regime.

Fase 1 er karakteriseret ved anastomoserende sprækkedannelse. Fase 2 er karakteriseret ved konjugerede forkastninger med associeret box-foldning.

Fase 3 udgør den dominerende foldefase og den mere eller mindre samtidige overskydningfase med udvikling af listriske overskydnings-vifter. Fase 4 består af overskydningen langs den store rampe med tilknyttet antithetisk revers forkastning, samt dannelsen af popup strukturer. Fase 5 indeholder dannelsen af den kataklastiske breccie, diatomit-glacitektonit, som blev udvalset langs sålen af det øvre moræneler.

Ud fra beregningerne på det vægtede tværprofil (Fig. 16) er dybden til decollementfladen for deformationen anslået til 80-100 m. Dette er sammenfaldende med den anslåede stratigrafiske dybde til den mest egnede bjergart for tektonisk glidning, nemlig bentoniten $i$ Holmehus Formationen.

Det glaciodynamiske event relateret til den tredie glaciodynamiske sekvens skyldes isfremst $\varnothing$ det fra den Norske Is, som overskred den nordlige del af Jylland fra c. 30.000 til 20.000 år før nutiden. Hastigheden af det deformerende isfremstød er estimeret til omkring $10 \mathrm{~m}$ om året. Strukturerne dannet under de glacialtektoniske faser passer ind i en model for en progressiv, glacialtektonisk deformation.

\section{References}

Aber, J. S., Croot, D. G. \& Fenton, M. M. 1989. Glaciotectonic landforms and structures. Quaternary Geology and Glaciology series, Kluwer Academic Publishers, Dordrecht, Netherlands, $200 \mathrm{pp}$.

Bahnson, H., Petersen, K. S., Konradi, P. B. \& Knudsen, K. L. 1974: Stratigraphy of Quaternary deposits in the Skærumhede II booring: lithology, molluses and foraminifera. Danmarks Geologiske Undersøgelse, Årbog 1973, 27-62.

Berthelsen, A. 1973. Weichselian ice advance and drift successions in Denmark. Bulletin of the Geological Institute University of Uppsala, New Ser., 5, 21-29.

Berthelsen, A. 1978. The methodology of kineto-stratigraphy as applied to glacial geology. Bulletin of the Geological Society of Denmark 27, 25-38.

Bøggild, O. B. 1918. Den vulkanske Aske i Moleret. Danmarks Geologiske Unders $\emptyset$ gelse II rk. 33, 84 pp.

Davis, G. H. 1984, Structural Geology of Rocks and Regions. John Wiley \& Sons, Inc., 492 pp.

Dahlström, C. D. A. 1969. Balanced cross sections. Canadian Journal of Earth Sciences 6, 743-757.

Gry, H. 1940. De istektoniske Forhold i Moleret. Meddelelser fra dansk geologisk Forening 9, 586-627.

Gry, H. 1979. Beskrivelse til Geologisk Kort over Danmark, kortbladet Løgstør. Danmarks Geologiske Undersøgelse, Ser. 1, 26, 58 pp.

Heilmann-Clausen, C., Nielsen, O. B. \& Gersner, F. 1985. Lithostratigraphy and depositional environments in the Upper Paleocene and Eocene of Denmark. Bulletin of the Geological Society of Denmark 33, 287-323.

Hobbs, B. E., Means, W. D. \& Williams, P. F. 1976. An Outline of Structural Geology. John Wiley \& Sons, Inc., 571 pp.

Houmark-Nielsen. M. 1987. Pleistocene stratigraphy and glacial history of the central part of Denmark. Bulletin of the Geological Society of Denmark 36, 1-189. 
Houmark-Nielsen, M. 1988. Glaciotectonic unconformities in Pleistocene stratigraphy as evidence for the behaviour of former Scandinavian ice sheets. In Croot, D.G. (ed.), Glaciotectonics: Forms and Processes, p. 91-99. A.A. Balkema, Rotterdam.

Hundahl, M. 1994. Resultatet fra en glacialgeologisk undersøgelse af kystklinterne omkring Thisted Bredning. In Pedersen, S.A.S. (ed.): Geology of the Mo-clay. Abstracts for the Mo-clay symposium on Mors. Danmarks Geologiske Undersøgelse, Service report 34, 1994.

Jakobsen, P. R. \& Pedersen, S. A. S. 1993: Geologisk opbygning af Junget molerfelt. Danmarks Geologiske Unders $\varnothing$ gelse, Service report 72, 1993, $30 \mathrm{pp}$.

Jessen, A. 1931. Lønstrup Klint. Danmarks Geologiske Unders $\emptyset$ gelse, II rk. 49, 142 pp. and atlas volume.

Klint, K. E. S. \& Pedersen, S. A. S. 1995. The Hanklit thrust fault complex, Mors, Denmark. Danmarks Geologiske Undersøgelse A 35, $32 \mathrm{pp}$.

Pedersen, A. K., Engell, J. \& Rønsbo. J. G. 1975. Early Tertiary volcanism in the Skagerrak: New chemical evidence from ash layers in the mo-clay of northern Denmark. Lithos 8, 255-268.

Pedersen, G. K. \& Surlyk, F. 1983. The Fur Formation, a late Paleocene ash bearing diatomite from northern Denmark. Bulletin of the Geological Society of Denmark 32, 4365.

Pedersen, S. A. S. 1987. Comparative studies of gravity tectonics in Quaternary sediments and sedimentary rocks related to fold belts. In: Jones, M. E. \& Preston, R. M. F. (eds): Sediment Deformation Mechanisms. Geological Society of London, Special Publication 29, 165-180.

Pedersen, S. A. S. 1988. Glacitectonite: Brecciated sediments and cataclastic sedimentary rocks formed subglacially. In Goldthwait, R. P. \& Matsch, C. L. (eds): Genetic classification of glacigenic deposits, A.A. Bal-kema, Rotterdam, 89-91.

Pedersen, S. A. S. 1989: Strukturgeologi ved Skarrehage molergrav. Danmarks Geologiske Unders $\varnothing$ gelse, Service report $19,1989,40 \mathrm{pp}$.

Pedersen, S. A. S. 1992: Molerundersøgelse af Helgasminde på Fur. Danmarks Geologiske Unders $\varnothing$ gelse, Service report 59, 1992, 18 pp.

Pedersen, S. A. S. 1993. Glaciodynamic Event and Glaciodynamic Sequence. In Aber, J. (ed.) Glaciotectonics and Mapping Glacial Deposits. Proceed. INQUA Comm. on Formation and Properties of Glacial Deposits. Canadian Plains Research Center, University of Regina, 67-85.

Pedersen, S. A. S. \& Petersen, K. S. 1986. Lerboring i Skarrehage. Unders $\emptyset$ gelsesboring gennem de nedre overgangslag i moleret i Skarrehage molergrav. Danmarks Geologiske Unders $\emptyset$ gelse, Intern rapport 16, 1986, $35 \mathrm{pp}$.

Pedersen, S. A. S., Petersen, K. S. \& Rasmussen, L.Aa. 1988. Observations onglaciodynamic structures at the Main Stationary Line in western Jutland, Denmark. In Croot, D.G. (ed.) Glaciotectonics: Forms and Processes, A.A. Balkema, Rotterdam, 177-183.

Petersen, K. S. \& Kronborg, C. 1991. Late Pleistocene history of the inland glaciation in Denmark. In Frenzel, B. (ed.): Klimageschichtliche Probleme der letzen 130000 Jahre. Paläoklimaforschung 1: 331-342.

Ramsay, J.G. 1967. Folding and fracturing of rocks. McGrawHill, New York, 568 pp.

Suppe, J. 1985. Principles of Structural geology. PrenticeHall, Inc. Englewood Cliffs, New Jersey, 537 pp.
Sørensen, H. \& Nielsen, A.V. (eds) 1978: The geological Mapping of Denmark. The present state of the mapping proposals for the future mapping. Report prepared by a working group. Danmarks Geologiske Undersøgelse A2, $79 \mathrm{pp}$.

Ussing, N.V. 1904. Danmarks Geologi i almenfatteligt Omrids. Danmarks Geologiske Undersøgelse, Ser. 3, No. 2, $358 \mathrm{pp}$.

Wateren, D.F.M. van der 1992. Structural geology and sedimentology of push moraines. Thesis, University of Amsterdam, 230 pp.

Fig. 1. Structural cross section of the Feggeklit coastal cliff (inserted as foldout figure inside the back cover of this volume). 
